\title{
Hydraulic and thermal fracturing techniques for successful stimulation in unconventional geothermal energy recovery
}

\author{
W.G.P. Kumari(1), P.G. Ranjith ${ }^{(2)}$, M.S.A. Perera ${ }^{(2,3)}$ and B. L. Avanthi Isaka ${ }^{(2)}$
}

(1) School of Civil, Mining and Environmental Engineering, 4-139, University of Wollongong, NSW 2522, Australia. (2) Department of Civil Engineering, Monash University, Building 60, Melbourne, Victoria, 3800, Australia.

(3) Department of Infrastructure Engineering, The University of Melbourne, Building 176 (Engineering Block D), Level 4, Room D 411, Grattan Street, Melbourne.

Ranjith.Pathegama.Gamage@monash.edu

\begin{abstract}
Unconventional or enhanced geothermal systems (EGSs) have been recently identified as potential geothermal resources which can be utilized to extract the heat trapped in the deep geological formations. However, due to the low formation porosity in these systems, an underground heat exchanger must be artificially created to enhance reservoir permeability. A number of reservoir stimulation techniques are adopted in EGSs to enhance their permeability, including hydraulic fracturing and thermal fracturing. The aim of the present work is to provide an in-depth understanding of these reservoir stimulation techniques based on our current laboratory experimental work. Recent literature on the topic has been comprehensively reviewed, and advanced laboratory tests have been conducted to understand hydraulic and thermal fracturing techniques under reservoir conditions. Experiments were conducted utilizing the high-temperature high-pressure rock tri-axial apparatus and quenching treatments were performed by injecting cold water into granite rocks heated to different temperatures. Flow-through experiments were also conducted on intact and fractured granite rocks and the results were compared to predict production enhancement upon stimulation. CT scanning technology was employed to determine micro-scale characteristics following stimulation. Experimental work revealed that the propagation paths and apertures of hydraulic and thermal fractures are controlled by the in-situ stress and temperature and the heterogeneity of the rock matrix. Although the induced fractures contributed substantial enhancement of reservoir permeability, they were sensitive to stress and temperature changes due to the larger effective stresses and thermally induced volumetric expansion.
\end{abstract}

Keywords: CT scanning, geothermal, hydraulic fracturing, permeability, thermal fracturing.

\section{Técnicas de fracturación hidráulica y térmica para la estimulación eficiente en la producción de energía geotérmica no convencional}

\author{
RESUMEN
}

Los sistemas geotérmicos mejorados o no convencionales (EGSs) se han identificado recientemente como recursos geotérmicos potenciales que se pueden utilizar para extraer el calor atrapado en formaciones geológicas profundas. Sin embargo, debido a la baja porosidad de formación en estos sistemas, se debe crear artificialmente un intercambiador subterráneo de calor para aumentar la permeabilidad del reservorio. En EGSs se han adoptado un número de técnicas de estimulación del reservorio para aumentar su permeabilidad, incluyendo la fracturación hidráulica y la fracturación térmica. El objetivo de este trabajo es proporcionar una comprensión profunda de estas técnicas de estimulación del reservorio basada en nuestro actual trabajo de experimentos en laboratorio. Se ha hecho una revisión exhaustiva de la literatura reciente en dicha temática, y se han llevado a cabo ensayos avanzados de laboratorio para entender las técnicas de fracturación hidráulica y térmica bajo condiciones del reservorio. Se llevaron a cabo experimentos utilizando equipos triaxiales para rocas a altas presiones y altas temperaturas y se realizaron tratamientos de temple por inyección de agua fría en rocas graníticas calentadas a diferentes temperaturas. También se llevaron a cabo experimentos de flujo continuo sobre rocas graníticas fracturadas e intactas y los resultados se compararon con la producción predicha con estimulación. Se empleó tecnología de escaneo CT para determinar las característica a micro-escala que se derivaban de la estimulación. El trabajo experimental ha revelado que la propagación de trayectorias y aperturas de fracturas hidráulicas y térmicas está controlado por esfuerzos y temperatura in-situ así como la heterogeneidad de la matriz rocosa. Aunque las fracturas inducidad contrubuyen sustancialmente al aumento de la permeabilidad del reservorio, eran igualmente sensitivas a cambios en los esfuerzos y temperatura debido al mayor esfuerzo efectivo y a la expansión volumétrica inducida térmicamente.

Palabras clave: escaneo CT, geotérmica, fracturación hidráulica, permeabilidad, fracturación térmica. 


\section{Introduction}

The conventional geothermal sector represents less than $1 \%$ of the world's electricity supply, mainly due to the limited availability of the resources in tectonic boundaries or volcanic areas. Unconventional geothermal resources have been identified as a promising energy technology, considering the localized resource accessibility of conventional geothermal resources (Hussain et al., 2017). These systems are identified as hot $\left(>150{ }^{\circ} \mathrm{C}\right)$ and dry crystalline or dense sedimentary rocks with intrinsic permeability less than $10^{-14} \mathrm{~m}^{2}$. As Fig. 1 shows, in order to extract the thermal energy trapped in these geological formations, water or other transmission fluids must be circulated through the reservoir. However, due to the low formation porosity, it is essential to create a large volume interconnected fracture network connecting the injection and production wells, allowing the circulation fluid to flow through the artificial reservoir with a sufficient residence time by engineering means to enhance the production of the reservoir. Since these systems are associated with engineering technology to enhance their performance, these systems are often referred to as enhanced or engineered geothermal systems (EGSs).

A number of reservoir stimulation techniques are adopted in EGSs to enhance their permeability, and hydraulic fracturing, which is commonly used in oil and gas reservoirs, is widely employed in the industry. This technology involves overcoming the fracturing pressure of the rock with hydraulic pressure by injecting a high-pressure fracturing fluid (usually water with a small percentage of chemical additives). A large planar hydraulic fracture is initially created perpendicular to the minimum horizontal stress direction, and during the opening of this major fracture created by tensile failure, significant numbers of micro-cracks are generated through shear failure in the surrounding rock matrix (Watanabe andTakahashi, 1995). However, compared to unconventional oil and gas reservoirs, the prediction of hydraulic fracturing process parameters and the hydraulically induced fracture volume is challenging in the EGS environment, due to the hightemperature and complex stress conditions.

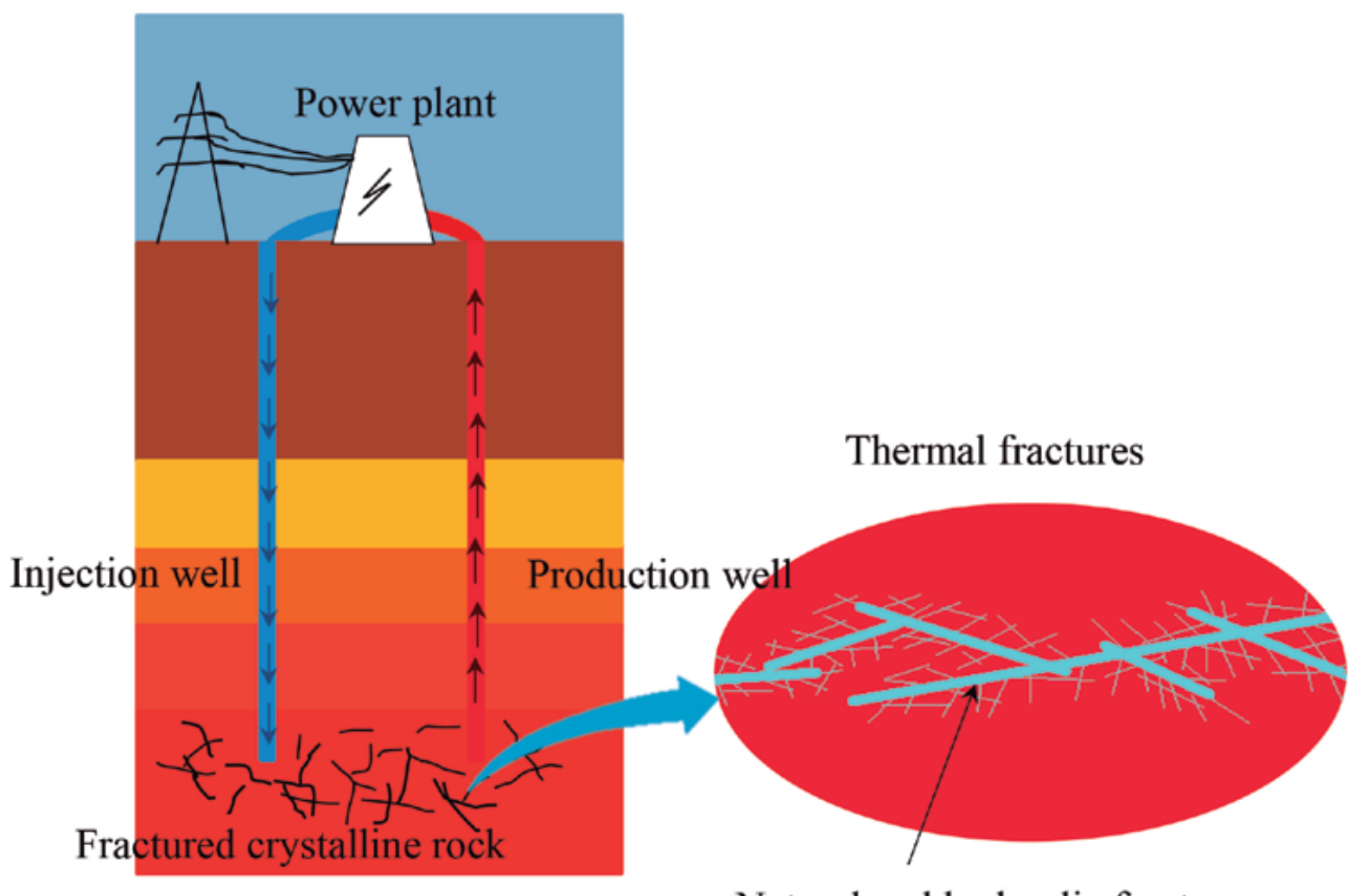

Natural and hydraulic fractures

Figura 1. Schematic representation of EGS with induced fractures.

Figura 1. Representación esquemática de EGS con fracturas inducidas. 
Apart from the main hydraulic fracture, the injection of cold water into hot rock has been hypothesized to result in additional fractures in the wellbore zone due to the associated thermal damage. This is referred to as thermal stimulation technology, and this method has been employed in underperforming geothermal wells to enhance near-wellbore permeability (Kitao et al., 1990). Under elevated thermal gradients, the initiation of propagation of fractures along grain boundaries and the grains themselves (inter-granular and intra-granular) has been identified. This thermal fracturing mechanism has been theorized as the differential thermal expansion of mineral grains which have different thermo-elastic moduli and thermal conductivities (Fredrich and Wong, 1986), and the subsequent rupture of the grain boundaries or grains, depending on the thermal energy and in-situ stress state. However, the physical, mechanical and microstructural alterations of the geothermal reservoir rock upon thermal stimulation and the associated permeability enhancement under reservoir conditions are not fully understood at present.

The replication of hydraulic and thermal stimulation techniques in a controlled laboratory environment provides fundamental insights into this technology and is the basis of the present research.

\begin{tabular}{|c|c|c|c|}
\hline Technique & Stimulation mechanism & $\begin{array}{l}\text { Recommended operational } \\
\text { parameters and nature } \\
\text { of induced fractures }\end{array}$ & References \\
\hline $\begin{array}{l}\text { Massive water } \\
\text { injection }\end{array}$ & $\begin{array}{l}\text { - This method relies on the self- } \\
\text { propping of the rock and the } \\
\text { potential of shear displacement } \\
\text { - Additional abrasive agents } \\
\text { (sand and low concentrations of } \\
\text { proppants) are used to enhance } \\
\text { conductivity by increasing the } \\
\text { fracture aperture } \\
\text { - It is recommended to use proppant } \\
\text { suspending agents and friction- } \\
\text { reducing agents which enhance } \\
\text { mechanical suspension of proppants }\end{array}$ & $\begin{array}{l}\text { - Fracturing fluid: water with } \\
\text { small proppant concentration } \\
\text { - Viscosity: } 1-10 \mathrm{cP} \\
\text { - Proppant concentration:50-200 } \\
\text { g/L } \\
\text { - Injection rates: up to } 150 \mathrm{~L} / \mathrm{s} \\
\text { - Fractures have long lengths (in } \\
\text { the range of } 100 \mathrm{~m} \text { ) with low } \\
\text { apertures of approximately } \\
1 \mathrm{~mm} \text { and hence low } \\
\text { conductivity }\end{array}$ & $\begin{array}{l}\text { (Hogarth et al., 2013; Schill } \\
\text { et al., 2015; Huenges, 2016) }\end{array}$ \\
\hline
\end{tabular}

Table 1. Current hydraulic stimulation practices and recommended operational parameters.

Tabla 1. Prácticas actuales de estimulación hidráulica y parámetros operacionales recomendados. 
Experiments were conducted utilizing the high-temperature high-pressure rock tri-axial apparatus available in the 3GDeep research laboratory (www.3gdeep. com) at Monash University, and thermal treatments were performed by injecting cold water into granite rocks heated to different temperatures. In addition, permeability experiments were conducted on intact and fractured granite rocks to understand the effect of in situ-stress and temperature changes and predict production enhancement upon stimulation. High-resolution CT scanning technology was employed to determine the micro-scale characteristics created by stimulation to reveal the science behind hydraulic and thermal fracturing. This included understanding the underlying mechanisms of fracture geometry, fracture propagation and thermally induced damage. Therefore, it is believed that the present work will provide a comprehensive understanding of the stimulation of geothermal reservoirs and contribute to both geothermal research and the industry.

\section{Technological background and literature review}

\section{Hydraulic fracturing technology}

Hydraulic stimulation involves the injection of pressurized water below the level of minimum in-situ stress in order to initiate and propagate new fractures. The increased pressure in the rock mass reduces the effective normal stress acting across the rock mass and natural fractures and promotes tensile fracture and shearing. Shearing-induced dilation results in the enhancement of permeability of the reservoir (Gischig and Preisig, 2015). Appropriate proppant types are generally employed to prop open the fractures created after releasing the applied pressure (Liang et al., 2016). This method enables the enhancement of the productivity index (PI) and the injectivity index (II) (i.e. the ratio between production or injection rate and the driving pressure gradient) up to $100-180 \%$, with fracture lengths ranging from 25 to $100 \mathrm{~m}$, respectively (Huenges, 2016). The fluid injection rate, the fluid injection method (continuous or intermittent), the properties of the injection fluid, including the quantity and quality of proppants and other additives which need to be included, and the fluid viscosity are the primary controlling parameters in this technology.

Hydraulic fracturing technology in geothermal reservoirs is at the trial-and-error stage and standards for the treatment and completion of wells have therefore not been established to date (Huenges, 2016). Generally, treatment design is site-specific and usually based on expertise on target section. Therefore, based on the dis- tinguishable properties of each section, treatments are carried out individually with hydraulic seals between sections. Considering past EGS stimulation exercises, three major hydraulic stimulation techniques can be identified: massive water injection; hydraulic-proppant treatment; and multistage treatment. Table 1 summarises current hydraulic stimulation practices and recommended operational parameters based on lessons learned in previous EGS projects.

\section{Laboratory-scale hydraulic fracturing experiments}

Laboratory-scale hydraulic fracturing experiments allow the simulation of hydraulic fracturing of real rock samples (homogeneous samples or samples with discontinuities) or artificial samples under controlled stress conditions. Therefore, they provide valuable information on hydraulic fracturing compared with the complexities associated with field-scale exercises.

The use of large cube-shaped samples enables the application of three independent stresses simulating field conditions (Fan and Zhang, 2014; Deng et al., 2016; Mao et al., 2017). However, it is important to distribute stresses uniformly throughout the sample faces and the friction generated between rams and the sample face is generally eliminated by use of Teflon sheet or grease as a lubricant. Cylindrical samples are also used, but in this case bi-axial stress conditions are simulated (Chitrala et al., 2013; Wanniarachchi et al., 2017). If natural rock samples are used, it is essential to core/cut, trim and polish the samples precisely. Therefore, artificial samples are sometimes prepared using concrete, cement mortar and Perspex (Fan and Zhang, 2014; Deng et al., 2016). However, in some situations it is questionable whether these studies are applicable to real rock applications in terms of their material properties (brittleness, cohesion, friction, porosity, permeability etc.). As Sarmadivaleh et al.(2013) indicate, homogeneous and smooth bore-holes need to be created to initiate hydraulic fractures. These researchers recommend drilling saturated samples employing a small drilling speed to ensure minimum damage to the samples. Alternatively, a hole with an axial notch can be prepared to facilitate fracture initiation. The open-hole section is also isolated with a metal bar which acts as a casing and the injection tube is then inserted. Some experiments have used glue forms to ensure a bond between the rock and the metal (Sarmadivaleh et al., 2013).

During hydraulic fracturing experiments, it is recommended to apply the stresses in steps (Sarmadivaleh et al., 2013). First, the in-situ stresses and temperatures are applied and then the fluid injection is 


\begin{tabular}{|c|c|c|c|}
\hline Reference & Details of sample & Test conditions & Major findings \\
\hline $\begin{array}{l}\text { (Zoback et al., } \\
\text { 1977) }\end{array}$ & $\begin{array}{l}\text { Cylindrical sandstone } \\
\text { specimens } 6 \mathrm{~cm} \text { long, } 3 \\
\mathrm{~cm} \text { in diameter } \\
\text { with an axial borehole } \\
2-3 \mathrm{~mm} \text { in diameter }\end{array}$ & $\begin{array}{l}\text { Fracturing fluid-water, room } \\
\text { temperature, pressurization } \\
\text { rate } 0.02-3.0 \mathrm{MNm}^{2} / \mathrm{s}\end{array}$ & $\begin{array}{l}\text { Breakdown pressure for both rocks in- } \\
\text { creases with pressurization rate }\end{array}$ \\
\hline (Blanton, 1982) & $\begin{array}{l}12 \times 12 \times 15 \text { inch naturally } \\
\text { fractured blocks of De- } \\
\text { vonian shale and hydro } \\
\text { stone; the angle of ap- } \\
\text { proach of the hydraulic } \\
\text { fracture to the pre-frac- } \\
\text { ture varied }\end{array}$ & $\begin{array}{l}\text { Fracturing fluid-water, con- } \\
\text { stant flow rate of } 0.05 \mathrm{cu} \text { in- } \\
. / \mathrm{s} \text {, room temperature }\end{array}$ & $\begin{array}{l}\text { Hydraulic fractures tend to cross pre-ex- } \\
\text { isting fractures only under high differen- } \\
\text { tial stresses and high angles of approach. } \\
\text { Mostly hydraulic fractures either divert- } \\
\text { ed or arrested by pre-existing fractures. } \\
\text { Fracture propagation in the vertical direc- } \\
\text { tion is influenced by bedding planes in } \\
\text { the shale which cause a step-like trace in } \\
\text { the vertical direction }\end{array}$ \\
\hline
\end{tabular}

(El Rabaa, 1989) Rock blocks of 6 × 12 × 18 in. with cased and perforated boreholes (different perforation lengths). The borehole directions varied from 0 to $90^{\circ}$

(Zhou et al., 2008) $300 \mathrm{~mm}$ cubic mixture of Chinese cement and sand blocks. Pre-fractures were created with different thicknesses (0.06-1.2 $\mathrm{mm}$ ) and angles
Fracturing fluid-water, injection rate $10 \mathrm{ml} / \mathrm{min}$, room temperature

Multiple fractures can be created from the same perforation interval when perforation length $\geq 4 \mathrm{D}$ and angle $<75^{\circ}$. The reorientation process when the angle is between $35^{\circ}$ and $75^{\circ}$ creates rough fracture walls.

Guar gum Fracturing flu- In a normal stress regime, fractures id-guar gum with viscosity of caused with interacting branches be$135 \mathrm{MPa}$, room temperature cause of pre-existing fracture. Tortuous injection rate $4.2 \times 10^{-9} \mathrm{~m}^{3} / \mathrm{s} \quad$ fractures are found along the direction of fracture height when one of the horizontal stresses is the maximum principle stress. When scaling laws are applied, stress level should also scale with the pre-existing fracture stiffness

\section{(Bunger et al.,} 2011)
$350 \times 350 \times 350 \mathrm{~mm}$ blocks of a medium grained gabbro with a $16 \mathrm{~mm}$ diameter hole to a depth of $290 \mathrm{~mm}$ and 4 notches of $1 \mathrm{~mm}$ depth around the circumference of the hole with different spacings

Fracturing fluid-water, room temperature

Near the wellbore complex fractures were identified, which means breakdown is not a straightforward process. This complexity persists as the fractures grow, resulting in deviating paths. More branching notching the wellbore results lower breakdown pressures and uniformity of access to the formation due to creation of additional fractures

(Chitrala et al., 2013)
Lyons sandstone 4 in. in Fracturing fluid- oil (viscosidiameter and with 0.25 ty $50 \mathrm{cp}$, room temperature in. hole drilled to mid- flow rate of $10 \mathrm{cc} / \mathrm{min}$. depth
At lower stresses, the hypocentres indicate a greater stimulated reservoir volume (AE study). SEM fracture morphology study showed a complex and non-planar development of the hydraulic fractures

Flow rate has different impacts on fracture complexity in hydraulic fracturing. At low flow rates $(<10 \mathrm{ml} /$ $\mathrm{min}$ ) hydraulic fractures propagate along natural fractures. At higher flow rates (>50 ml/min) deviate from maximum horizontal stress direction. With higher horizontal stress difference hydraulic fractures tend to deviate from natural fractures 


\begin{tabular}{|c|c|c|c|}
\hline $\begin{array}{l}\text { (Fan and Zhang, } \\
\text { 2014) }\end{array}$ & $\begin{array}{l}\text { Cubic specimens of } \\
300 \mathrm{~mm} \text { made of cement } \\
\text { and sand. Natural frac- } \\
\text { tures were created with } \\
\text { two groups of orthogonal } \\
\text { cemented fractures }\end{array}$ & $\begin{array}{l}\text { Fracturing fluid-water, room } \\
\text { temperature injection rate } \\
0.10-0.16 \mathrm{ml} / \mathrm{s}\end{array}$ & $\begin{array}{l}\text { A greater natural fracture density and } \\
\text { a higher injection rate tend to raise the } \\
\text { treatment pressure. At low injection } \\
\text { pressures hydraulic fractures steadily ex- } \\
\text { tended while higher injection pressures } \\
\text { resulted in unstable fracture propagation }\end{array}$ \\
\hline $\begin{array}{l}\text { (Fallahzadeh et al., } \\
2015 \text { ) }\end{array}$ & $\begin{array}{l}10 \text { and } 15 \mathrm{~cm} \text { cubic } \\
\text { samples made of syn- } \\
\text { thetically manufactured } \\
\text { tight mortar (UCS } 79.5 \\
\mathrm{MPa}, \mathrm{E}-27.7 \mathrm{GPa} \text {, tensile } \\
\text { strength } 3.5 \mathrm{MPa} \text { ) with } \\
\text { perforated boreholes }\end{array}$ & $\begin{array}{l}\text { Fracturing fluid-silicon oil } \\
\text { (viscosity } 97,700 \mathrm{cp} \text { ) pres- } \\
\text { sure of } 5,000 \mathrm{psi} \text { and tem- } \\
\text { perature of } 28^{\circ} \mathrm{C} \text {. flow rate } \\
\text { of } 0.05-0.1 \mathrm{cc} / \mathrm{min}\end{array}$ & $\begin{array}{l}\text { In a perforated wellbore, the increase in } \\
\text { the stress anisotropy affects the fractur- } \\
\text { ing pressure. } \\
\text { When the axes of perforations are ori- } \\
\text { ented in the directions of perpendicular } \\
\text { to intermediate and maximum stresses } \\
\text { larger fracture initiation and breakdown } \\
\text { pressures are required }\end{array}$ \\
\hline (Mao et al., 2017) & $\begin{array}{l}1000 \times 1000 \times 1000 \mathrm{~mm} \text { of } \\
\text { Luhui Granite with } 83 \mathrm{~mm} \\
\text { diameter drill hole drilled } \\
\text { to the centre of sample }\end{array}$ & $\begin{array}{l}\text { Fracturing fluid-water, injec- } \\
\text { tion rate } 10 \mathrm{ml} / \mathrm{min} \text {, room } \\
\text { temperature Acoustic emis- } \\
\text { sions has employed }\end{array}$ & $\begin{array}{l}\text { New cracks initiate from the tip of the } \\
\text { pre-manufactured crack under different } \\
\text { loading conditions. When the horizontal } \\
\text { stress difference approached the average } \\
\text { tensile strength value of the specimens, } \\
\text { the crack propagation path on the surface } \\
\text { of the specimens became irregular. }\end{array}$ \\
\hline . 2016) & $\begin{array}{l}300 \times 300 \times 300 \mathrm{~mm} \text { ce- } \\
\text { ment blocks and } \\
\text { pit shaft } 30 \mathrm{~mm} \text { in diame- } \\
\text { ter and } 150 \mathrm{~mm} \text { long }\end{array}$ & $\begin{array}{l}\text { Fracturing fluid- guar gum } \\
\text { with viscosity of } 135 \mathrm{mPa} \text {, } \\
\text { room temperature }\end{array}$ & $\begin{array}{l}\text { The notch angle influences the initiation } \\
\text { and propagation directions. When the } \\
\text { notch plane is perpendicular to the di- } \\
\text { rection of the minimum principal in-situ } \\
\text { stress, both the initiation and propaga- } \\
\text { tion directions of hydraulic fractures are } \\
\text { perpendicular to the direction of the min- } \\
\text { imum principal in-situ stress. Otherwise, } \\
\text { the initiation direction of the fracture } \\
\text { is first along the direction of the notch } \\
\text { plane, but the final propagation direction } \\
\text { of fracture turns to perpendicular to the } \\
\text { direction of the minimum principal in-si- } \\
\text { tu stress. The longer the notch length, the } \\
\text { smaller the initiation pressure, and the } \\
\text { faster and farther the fracture propagates. }\end{array}$ \\
\hline (Zhc & $\begin{array}{l}200 \times 400 \mathrm{~mm} \text { grey gran- } \\
\text { ite with injection hole } \\
18 \mathrm{~mm} \text { in diameter and } \\
250 \mathrm{~mm} \text { long. Fracturing } \\
\text { section } 50 \mathrm{~mm}\end{array}$ & $\begin{array}{l}\text { Fracturing fluid-water. Tem- } \\
\text { perature upto } 400{ }^{\circ} \mathrm{C} \text { with } \\
\text { heating rate of } 10{ }^{\circ} \mathrm{C} / \mathrm{h} \text {, } \\
\text { steady increase of pressure }\end{array}$ & $\begin{array}{l}\text { Thermal cracking occurs in the sample } \\
\text { due to high temperature. This results in } \\
\text { reduction of fracture initiation pressure } \\
\text { with increasing temperature. }\end{array}$ \\
\hline
\end{tabular}

Table 2. Summary of selected laboratory hydraulic fracturing experiments.

Tabla 2. Resumen de los experimentos seleccionados de fracturación hidráulica en laboratorio.

initiated. In order to regulate the flow of a large volume, it is recommended to use a flow restriction device which can be done by a slightly open needle valve located close to the injection point (Bunger et al., 2005; Sarmadivaleh et al., 2013). Table 2 summarises a number of selected laboratory hydraulic fracturing experiments in terms of their sample description, test conditions and major outcomes.

\section{Thermal fracturing technology}

In the case of geothermal reservoirs which experience continuous thermal stresses due to the injection of cold fluid into the hot rock mass, injecting fluids colder than the hot reservoir rock with a period of thermal recovery between each injection scenario can be expected to cause thermal cracking due to the induced thermal shock. This can result in potential multiple 
fractures perpendicular to the main fracture (Tarasovs and Ghassemi, 2011). In addition, it is expected to reopen existing, possibly sealed, fractures with thermal stresses. This technique has been utilized in high enthalpy reservoirs in volcanic and metamorphic formations, including in Larderello (Italy) and the Northwest Geysers, Coso and Newberry (USA)(Breede et al., 2013). It is a promising technology in ongoing/future deep geothermal well-drilling projects, including in supercritical EGSs which experience large geothermal gradients.

As a result of thermal stresses, thermally-induced cracks can be initiated by several mechanisms, including the mis-match between the thermo-elastic coefficients of different minerals, which leads to anisotropic thermal expansion, heterogeneous thermal gradients, thermally-induced volumetric expansion and thermo-chemical reactions of the rock mass (Dmitriev, 1972; Wong and Brace, 1979; Fredrich and Wong, 1986; Heard, 1989; Yasuhara and Elsworth, 2008). According to Wong and Brace (1979), when the internal stress of the rock mass exceeds the crack closure pressure with increasing temperature, thermal cracks are initiated:

$$
\sigma=E \Delta \alpha \Delta \mathrm{T}
$$

where, $\mathrm{E}, \Delta \alpha, \Delta \mathrm{T}$ is the matrix Young's modulus, and the difference of the thermal expansion coefficient of distinct mineral and temperature difference, respectively. Large temperature differences associated with thermal stimulation can result in significant damage to the rock structure. Induced cracks can be propagated along mineral boundaries (inter-crystalline/granular cracks) or in the minerals themselves (intra-crystalline granular cracks).

\section{Laboratory-scale thermal fracturing experiments}

Compared with laboratory-scale hydraulic fracturing experiments, thermal fracturing exercises are limited due to the necessity of appropriate instrumentation. Recent experimental work by Siratovich et al. (2015) replicated thermal stimulation by injecting cold water into a heated rock at $375{ }^{\circ} \mathrm{C}$ and $35 \mathrm{MPa}$. As shown in Fig. 2(a), the acoustic emission (AE) counts recorded during the thermal stimulation process clearly captured the physical damage to the rock mass upon injection of cold water. A significant number of $A E$ counts were recorded during the quenching process which indicates the initiation and propagation of thermally induced cracks.

Thermal processing of rocks can induce large variations in their mechanical and physical properties, including a reduction of strength and elastic modulus and an increase of porosity and permeability. Investigations of the correlations between the mechanical characteristics of crystalline rocks (compressive strength, tensile strength, and Young's modulus) and thermal treatment have identified a general negative correlation (Heuze, 1983; Dwivedi et al., 2008). However, only a few studies have focused on the mechanical response of thermally-stimulated quenched rocks, which is a critical concern to ensure wellbore integrity (Shao et al., 2014; Shao, 2015). Fig. 2(b) is a clear representation of permeability enhancement upon thermal treatment, and indicates that both porosity and permeability are enhanced by several orders upon thermal stimulation (Siratovich et al., 2015). This study was conducted at 325 ${ }^{\circ} \mathrm{C}, 20 \mathrm{MPa}$ confining pressure and $145 \mathrm{ml} / \mathrm{min}$ injection flow rate. However, it is important to evaluate the flow performance of thermally treated samples under different stress and temperature conditions, in order to obtain a better understanding of the flow enhancement of stimulated reservoirs.

In order to determine production enhancement in geothermal reservoirs an understanding of the connected porosity and throat diameter is essential since the contribution of isolated pores is meagre for the fluid transport of low permeable crystalline rocks. A number of studies have considered enhanced porosity upon thermal treatment (Wong, 1982; Fredrich and Wong, 1986; Shao, 2015), and as shown in Fig. 2(c), the experimental results of Geraud (1994) on granite samples showed an increment of unconnected and mixed porosities with increasing temperature. However, with thermal treatment, the porosity of connected channels decreased slightly, possibly due to the induced volumetric expansion. However, this experiment was conducted under slow cooling rates and the effect of quenching on rock micro-structure remains poorly understood to date.

\section{Research method}

\section{Testing material}

Granite specimens were collected from Victoria, Australia. The selected granites were a coarse grain type with grain size ranges between $0.2 \mathrm{~mm}$ to $0.5 \mathrm{~mm}$, with only a few larger grains $(>3 \mathrm{~mm})$. Table 3 shows the physical and petrographic properties of the selected granite under room temperature and pressure conditions. The mineralogical composition was quantitatively obtained from the XRD analysis, and it was found that the selected granite consists of quartz, $\mathrm{K}$ feldspar, plagioclase, and biotite. A close-up view of a typical granite sample, a reconstructed $3-D$ view 
obtained from micro CT experiments and the cross section are illustrated in Fig. 3. The CT images were post-processed with AVIZO 9.1 software and different colours represent different minerals. The green regions represent the relatively less dense areas (quartz and feldspar), and the yellow regions represent the highly dense areas (biotite mineral). Granite specimens were cored to a $22.5 \mathrm{~mm}$ diameter for hydraulic and thermal fracturing experiments and the cylindrical cores were then cut to $45 \mathrm{~mm}$ employing a diamond cutter. Core samples with visible cracks were discarded. The sample surface was then smoothed with surface irregularity less than $10 \mu \mathrm{m}$ by grinding the two surfaces.

\section{High-temperature hydraulic fracturing experiments}

Laboratory-scale hydraulic fracturing experiments were conducted utilizing the high-pressure high- temperature triaxial testing apparatus (Shao, 2015). This unique apparatus is capable of injecting fluid up to $165 \mathrm{MPa}$, with maximum confining pressures of 137 $\mathrm{MPa}$, maximum axial loads up to $1000 \mathrm{kN}$ and temperature up to $350^{\circ} \mathrm{C}$. In order to simulate the wellbore and to initiate a hydraulic fracture, sample centres were drilled to mid-depth employing a $3 \mathrm{~mm}$ drill bit. Hydraulic experiments were conducted for different temperature ranges from room temperature to $300{ }^{\circ} \mathrm{C}$ for different stress conditions (confining pressure up to $60 \mathrm{MPa}$ ). Throughout all the experiments, the axial load was controlled to apply $2 \mathrm{kN}$ of deviatoric force. This ensured a larger axial stress than confining pressure, which results in initiation of hydraulic fractures along the wellbore (vertical plane) (El Rabaa, 1989). The target temperature and pressure were applied and maintained for 3 hours prior to fluid injection to ensure that a uniform temperature and pressure were applied throughout the sample prior to the fracturing experiment. Water was used as the fracturing fluid, and water at room temperature was injected employing at a constant rate of $5 \mathrm{ml} / \mathrm{min}$ until sample failure.

\section{Thermal fracturing experiments}

Quenching treatment was employed to induce thermal fractures, and cold water was injected into the heated samples to produce a large thermal gradient, which results in sudden thermal expansions in the anisotropic rock structure with a number of thermal cracks. In order to understand the effect of the thermal gradient, samples were heated to different target temperatures up to $800^{\circ} \mathrm{C}$ and the corresponding physical and mechanical response were studied. Significant thermal damage was observed beyond $600{ }^{\circ} \mathrm{C}$ and therefore, samples treated under $600^{\circ} \mathrm{C}$ were used for detailed micro-scale experiments (pore-network modelling) and flow-through experiments.

\section{Flow through experiments}

Drained permeability tests were conducted to obtain a quantitative and qualitative measurement of both intact and fractured (hydraulically and thermally) specimens. Intact/ fracture permeability tests were conducted using water injections at different injection pressures under $30 \mathrm{MPa}$ confining pressure. Throughout all the experiments, the axial load was controlled to apply pressure equal to the confining pressure such that $\sigma_{1}=\sigma_{3}$. The downstream flow mass was then recorded using an electronic balance with the sensitivity of $0.01 \mathrm{~g}$ and the corresponding steady-state flow rates and permeability values were calculated employing Darcy's law.

\section{Micro-structural studies}

A detailed micro-scale study was conducted employing micro CT scanning and scanning electron microscopy (SEM) with energy dispersive $\mathrm{x}$-ray (EDX) to understand and quantify the hydraulic and thermal fracturing. The Imaging and Medical beamline (IMBL) of the Australian synchrotron was used for the CT scanning, which allowed higher contrast at high resolution (10 $\mu \mathrm{m}$ voxels). The Avizo 9.1 software was utilized to identify the induced hydraulic and thermal fractures. The induced fractures were transformed into a pore network model allowing in-depth understanding of connected and isolated pore channels.

\section{Results and discussion}

\section{Hydraulic fracturing experimental results}

A typical pressure-time curve corresponding to a hydraulic fracturing operation is illustrated in Fig. 4(a). As shown in the figure, initially a small pressure development region can be identified due to the filling of the wellbore, accessible pores and pre-existing fractures of the specimen. Next, a linear pressure development can be identified, referred to as the 'well-bore pressurization' stage. With the development of sufficient negative effective stress (confining pressure < injection pressure), a hydraulic fracture initiates resulting in release of the fracturing fluid through the induced fracture. This results in a sudden reduction of fluid pressure. However, due to the pressure release, the induced fracture results in a residual pressure. Usual- 


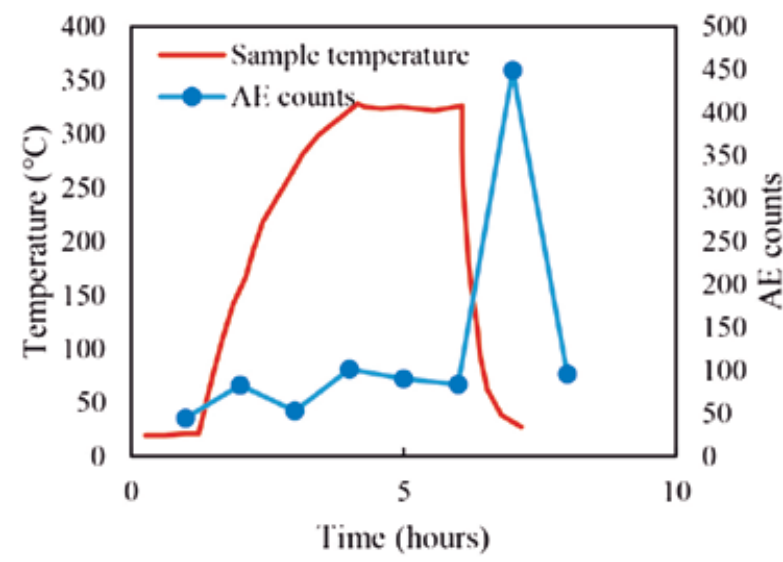

(a) Crack development during quenching treatment (Siratovich et al., 2015)

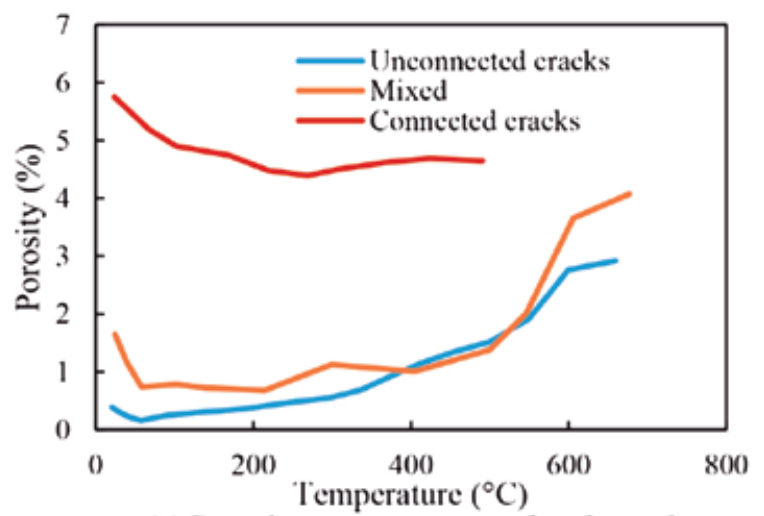

(c) Porosity measurements after thermal treatment (Geraud, 1994)

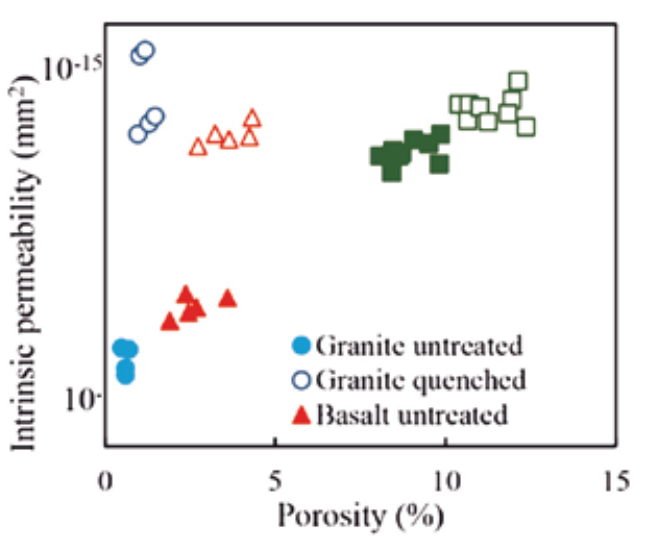

(b) Variation of permeability and porosity upon thermal treatment (Siratovich et al., 2015)

Figure 2. Results of selected thermal fracturing experiments. (a) Crack development during quenching treatment (Siratovich et al., 2015). (b) Variation of permeability and porosity upon thermal treatment (Siratovich et al., 2015). (c) Porosity measurements after thermal treatment (Geraud, 1994).

Figura 2. Resultados de experimentos seleccionados de fracturación térmica. (a) Desarrollo de grietas durante el tratamiento de temple (Siratovich et al., 2015). (b) Variación de permeabilidad y porosidad en el tratamiento térmico (Siratovich et al., 2015). (c) Medidas de porosidad después del tratamiento térmico (Geraud, 1994).

ly, this residual pressure is equal to the corresponding confining pressure (Sarmadivaleh et al., 2013). In order to overcome the closure of fractures, proppants, which are typically sand or man-made ceramic particles, are injected. The fluid injection can be continued, which results in the secondary fracturing stage. The induction of secondary cracks can also be identified with the later pressure drops of the pressure-time curve.

Fig. 4(b) illustrates selected pressure-time curves of granite samples fractured under different stress and temperature conditions. The curves follow the typical pressure-time relationships of hydraulic fracturing tests, as discussed in previous sections. Following the linear wellbore pressurization region, sample fracturing was identified with the sudden pressure drop, and this was ensured by observing a down- stream fluid flow. It was observed that the duration of wellbore pressurization increases with increasing confining pressure due to the increment of necessary negative effective stress to create the hydraulic fracture. Interestingly, compared with room temperature experiments, longer duration of initial pressure development was observed with high-temperature hydraulic fracturing experiments for all the confining pressures. Further, the rate of wellbore pressurization decreased with increasing temperature. These observations can be explained by the alteration of fracturing fluid properties and the rock matrix with increasing temperature. Although water is injected at room temperature, since the fluid flow line is inside the pressure cell which is under high temperature, it is reasonable to assume that the water entering the sample is at a cer- 
tain temperature higher than the room temperature but lower than the cell/sample temperature (considering the injection rate and duration). Therefore, the viscosity of the water is lower than that under room temperature conditions while the compressibility of the water is higher (Lemmon et al., 2002). However, due to the temperature difference between the rock and injection fluid, there is a thermal gradient close to the wellbore zone, which results in a substantial thermal damage to the wellbore zone with thermally induced micro-fractures. This enhances fluid leak-off from the granite rock. These phenomena cause longer initial pressure development and a lower rate of wellbore pressurization during high-temperature hydraulic fracturing experiments.

\section{Effect of pressure and temperature on breakdown pressure}

The estimation of breakdown pressure and fracture propagation pressure is essential to identify the optimum parameters of the hydraulic process (pumping requirements and stages of fracturing). These parameters depend on the reservoir properties, including the in-situ stress and temperature as well as the mechanical characteristics and mineralogy of the rock. Fig. 5 summarizes the breakdown pressure values obtained for different temperatures and pressures from the present laboratory experiments. The figure shows that the breakdown pressure increases linearly with confining pressure, while it decreases linearly with increasing temperature. The rate of reduction decreases with increasing confining pressure. The linear reduction of the tensile strength of granite with increasing temperature is analogous with the linear reduction of the breakdown pressure of granite with increasing temperature (Kumari et al., 2017).

Two classical hydraulic furcating criteria determine breakdown pressure based on in-situ horizontal principal stresses. The well-known Hubbert and Wills (HW) criterion (Eq.2) is based on elastic theory for impermeable rocks (Hubbert and Willis, 1957), while the Haimson and Fairhurst criterion (Eq. 3) is based on poro-elastic theory (Haimson and Fairhurst, 1967). This equation considers the poro-elastic stress induced by fluid permeation into rocks.

$$
\begin{gathered}
P_{b}=3 \sigma_{h}-\sigma_{H}+\sigma_{T}-P_{0} \\
P_{b}=\frac{3 \sigma_{h}-\sigma_{H}+\sigma_{T}-P_{0}}{2(1-\eta)}
\end{gathered}
$$

where, $P_{b}$ is the breakdown pressure, $\sigma_{H}$ is the minimum horizontal stress, $\sigma_{T}$ is the maximum horizontal stress, $\sigma_{T}$ of the formation, $P o$ is the initial pore pressure, and $\eta$ is the poro-elastic parameter which is defined as:

$$
\eta=\frac{\beta(1-2 v)}{2(1-v)} \quad 0 \leq \eta \leq 0.5
$$

where, $\beta$ is the Biot parameter and $v$ is the Poisson's ratio.

However, considering the high-temperature condition, it is essential to consider the effect of thermal stresses on the hydraulic fracturing process. According to the theoretical work of Stephens and Voight (1982), the breakdown pressure of an impermeable formation under thermal stresses can be estimated as follows:

$$
P_{b}-P_{0}=3 \sigma_{h}-\sigma_{H}+\sigma_{T}-\frac{\alpha E \Delta T}{1-v}
$$

where, $T$ is the temperature, $v$ is the Poisson's ratio, $E$ is the Young's modulus, and $\alpha$ is the coefficient of thermal expansion of the formation.

In the present study, under triaxial conditions, the minimum and maximum horizontal stresses are equal to the confining pressure $(\sigma)$. Therefore, assuming water can flow through the induced fractures and pores and combining Equations 3-5, a theoretical relationship for the breakdown pressure for the present condition can be obtained as follows:

$$
P_{b}-P_{0}=\frac{2 \sigma_{c}+\sigma_{T}}{2(1-\eta)}-\frac{\alpha E \Delta T}{1-v}
$$

In Eq. (5), breakdown pressure is a function of the confining pressure, temperature, and material properties of the rock. However, it should be noted that the material properties of a rock mass (tensile strength, Young's modulus, Poisson's ratio and coefficient of thermal expansion) are temperature-dependent, and the injection of cold water into a hot rock formation may result in thermally induced micro-cracks. Further, thermal damage can enhance the porosity and permeability of the rock matrix. These complexities have not been incorporated in estimating the breakdown pressure in Eq. 6.

An empirical relationship was developed to estimate the breakdown pressure of granite under different in-situ stress and temperature conditions for the present experimental conditions as follows:

$$
P_{h}-P_{n}=1.123 \sigma_{r}+\sigma_{T}(T)-0.009 \Delta T \quad 20 \leq T \leq 300
$$


where, temperature and pressure should be presented in ${ }^{\circ} \mathrm{C}$ and $\mathrm{MPa}$. This equation is analogous with Eq. 6 with $E=17.5 \mathrm{GPa}$ and $v=0.24$, which were obtained from laboratory experiments where $\beta=1$ and $a=5.43 \times 10^{-6}{ }^{\circ} \mathrm{C}^{-1}$ which are reasonable for water and granite, respectively. However, the estimated pressure was $25 \%$ lower than the result of the theoretical equation, possibly due to the induced thermal damage, enhanced fluid leak-off and change of fluid properties, which are not incorporated in the theoretical equation.

\section{Fracture propagation during hydraulic fracturing}

Understanding fracture geometry and the mechanism of hydraulic fracture propagation is necessary to understand the propagation of the fracture system. The reservoir properties (in-situ stress state, temperature, mechanical characteristics, and mineralogy), the fracturing process parameters (injection flow rate and stages of fracturing), the properties of the fracturing fluid (density, viscosity and compressibility) and the characteristics of discontinuities (presence of natural fractures, bedding planes, and associated heterogeneity) govern the fracture propagation process.

The stress state of the formation is the dominant factor determining fracture orientation and the morphology. Zoback et al.(1977) found that a hydraulic fracture is always propagated along the major principal stress. Further, the difference of horizontal stresses determines breakdown pressure, shape, quantity and fracture propagation (i.e. either single or multiple
fractures)(EI Rabaa, 1989). The temperature also plays a critical role during the hydraulic fracturing process, such that due to the injection of cold fluid into rock fractures, thermally-induced micro-cracks can be propagated, particularly close to the wellbore (Kumari et al., 2018). In order to understand the micro-scale features of hydraulically fractured granite, samples were CTscanned at $10 \mu \mathrm{m}$ resolution and the $\mathrm{CT}$ images were enhanced and reconstructed using Avizo 9.2 to understand the fracture profile. Fig. 6 illustrates a selected 3-D profile of hydraulically fractured granite and the separate fractures after hydraulic fracturing experiments conducted at room temperature and $0.1 \mathrm{MPa}$ confining pressure. The figure shows that increasing confining pressure results in a substantial reduction of the induced fracture aperture due to the closure of the fracture with the induced normal stresses in the absence of proppants. In addition, although there are local variations, the fracture aperture decreases linearly with fracture length, due to the reduction of free energy while the fracture propagates. Different mineral constituents affect the fracture propagation differently, and fractures mainly tend to propagate along quartz-quartz boundaries, biotite-quartz boundaries, and along large quartz and biotite grains. In addition, the CT images confirmed the presence of a perforated zone with multiple inter-crystalline cracks in the wellbore zone apart from the main hydraulic fracture under high-temperature hydraulic fracturing. A detailed discussion of the micro-scale features of hydraulic fracturing can be found in Kumari et al. (2018).
Mineralogical distribution

Bulk density $\left(\mathrm{kg} / \mathrm{m}^{3}\right)$

Porosity (\%)

Uniaxial compressive strength (MPa)

Young's modulus (GPa)

Poisson's ratio

Brazilian tensile strength (MPa)

\begin{tabular}{|c|c|c|}
\hline Mineral & Chemical formula & Composition by weight \\
\hline Alpha quartz & $\mathrm{SiO}_{2}$ & 50 \\
\hline Plagioclase & $\mathrm{Na}-\mathrm{CaAlSi}{ }_{3} \mathrm{O}_{8}$ & 16 \\
\hline Biotite & $\mathrm{K}(\mathrm{Mg} \cdot \mathrm{Fe})_{3} \mathrm{AlSi}_{3} \mathrm{O}_{10}$ & 15 \\
\hline K-feldspar & $\mathrm{KAISi}_{3} \mathrm{O}_{8}$ & 13 \\
\hline Muscovite & $\mathrm{Al}_{3} \mathrm{Si}_{3} \mathrm{O}_{10}(\mathrm{OH})_{2}$ & 2 \\
\hline Clinochlore & $\left(\mathrm{Mg}, \mathrm{Fe}^{2+}\right)_{5} \mathrm{Al}_{2} \mathrm{Si}_{3} \mathrm{O}_{10}(\mathrm{OH})_{8}$ & 2 \\
\hline Other minerals & - & 2 \\
\hline
\end{tabular}

2703.4

1.2

120.94

17.13

0.24

7.85

Table 3. Physical and petrographic properties of selected granite under room temperature and pressure conditions.

Tabla 3. Propiedades físicas y petrográficas de los granitos seleccionados bajos condiciones ambientales de presión y temperatura en laboratorio. 


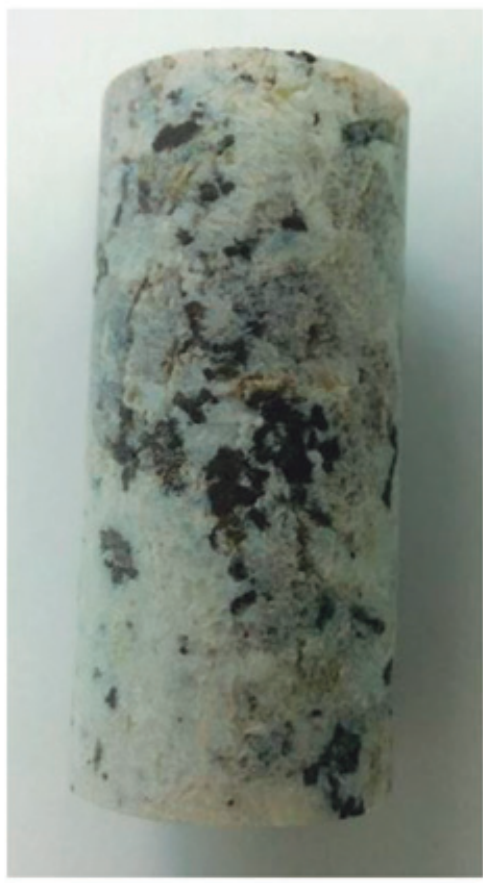

(a) Close-up view of granite

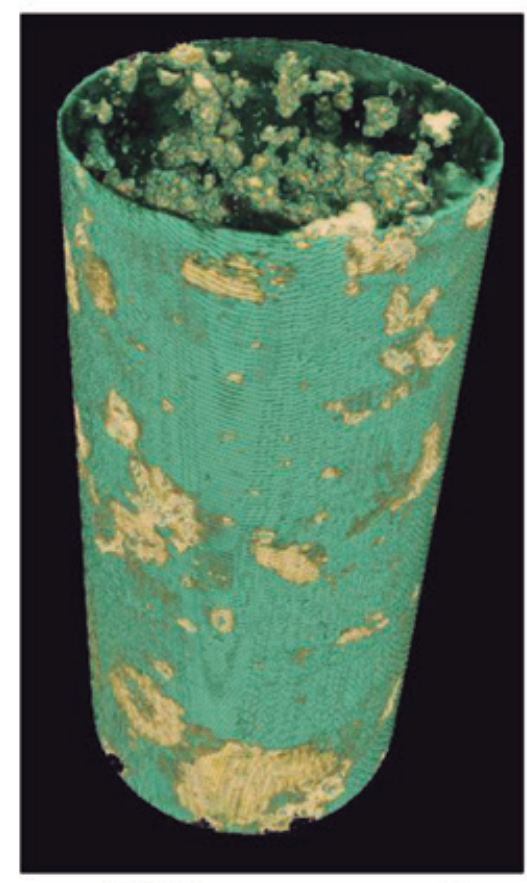

(b) Re-constructed micro-CT image of intact granite

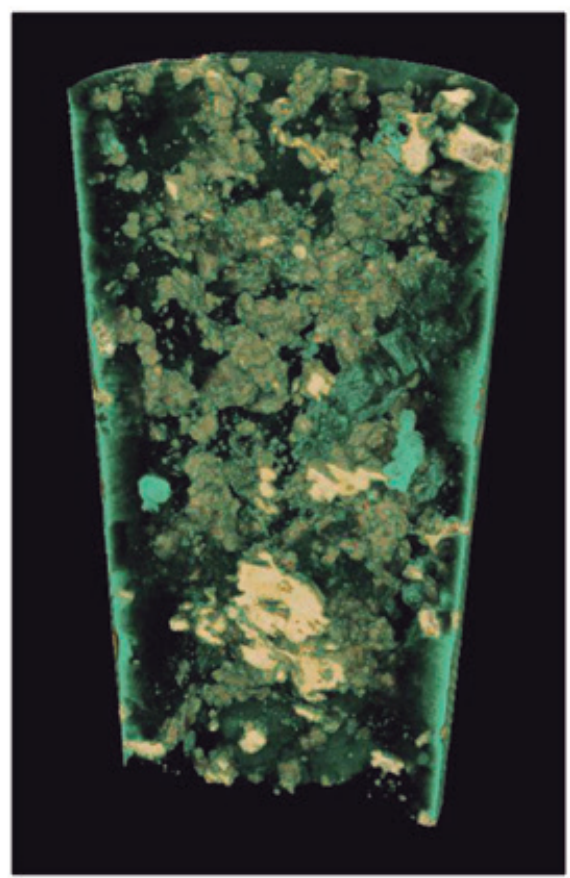

(c) Re-constructed cross section of intact granite

Figure 3. Selected Australian Strathbogie granite. (a) Close-up view of granite. (b) Re-constructed micro-CT image of intact granite. (c) Re-constructed cross section of intact granite.

Figura 3. Granito Australian Strathbogie seleccionado. (a) Vista en detalle del granito. (b) Imagen CT reconstruida del granito intacto. (c) Sección reconstruida del granito intacto.

\section{Thermal fracturing experimental results}

In order to understand the thermal fracturing process, experiments were conducted by injecting cold water into heated samples at different target temperatures from room temperature to $800{ }^{\circ} \mathrm{C}$. The physical, mechanical and micro-structural responses of the samples were investigated, and the experimental results are summarised as follows.

\section{Physical and mechanical responses of thermally frac- tured rocks}

The physical changes in the granite due to the quenching process were investigated using high-resolution photographs of the surface of the $2 \mathrm{~mm}$ thick specimens. Fig. 7 illustrates the appearance of a selected specimen across a wide range of temperatures (room temperature to $800^{\circ} \mathrm{C}$ ). It should be noted that for comparison purposes the same granite slice was treated at different temperatures. The figure shows that the physical changes of the granite specimens quenched up to
$200{ }^{\circ} \mathrm{C}$ are insignificant. However, a clear alteration of the colour of the granite was observed beyond $400{ }^{\circ} \mathrm{C}$ from grey-black to reddish grey-black with increasing thermal gradient. This physical alteration is attributed to dehydration of the granite and oxidation of minerals (Hajpál and Török, 2004). Further, a substantial increment of crack density was observed beyond 400 ${ }^{\circ} \mathrm{C}$ and, the crack density of the specimens was qualitatively determined using the open source software Image J. The crack densities of $400{ }^{\circ} \mathrm{C}, 600{ }^{\circ} \mathrm{C}$, and $800{ }^{\circ} \mathrm{C}$ were calculated to be $4.5 \%, 7.7 \%$, and $12.3 \%$, respectively. Under $400^{\circ} \mathrm{C}$, mainly inter-granular cracks were observed while increased temperature resulted in the extension and increase of the fracture aperture of the induced cracks and the induction of new inter- and intra- granular cracks. Interestingly, at $800{ }^{\circ} \mathrm{C}$ both macroscopic (fracture aperture $>20 \mu \mathrm{m}$ ) and microscopic fractures (fracture aperture $<20 \mu \mathrm{m}$ ) were observed which ultimately resulted in the loss of sample integrity.

Next, the mechanical response of the thermally fractured granite was investigated by conducting uni- 


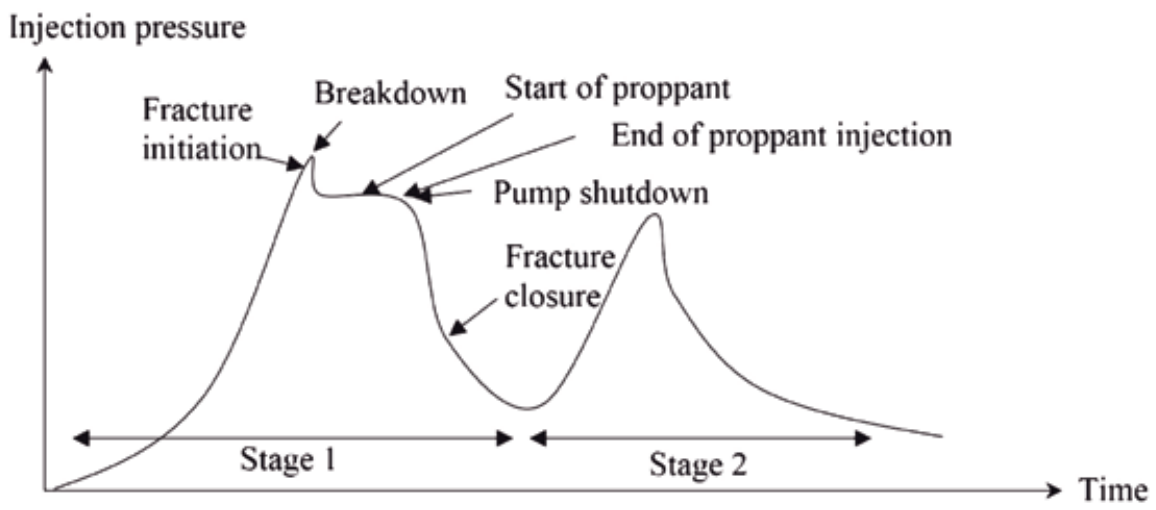

(a) Typical pressure time curve in hydraulic fracturing experiment (Sarmadivaleh, 2012)

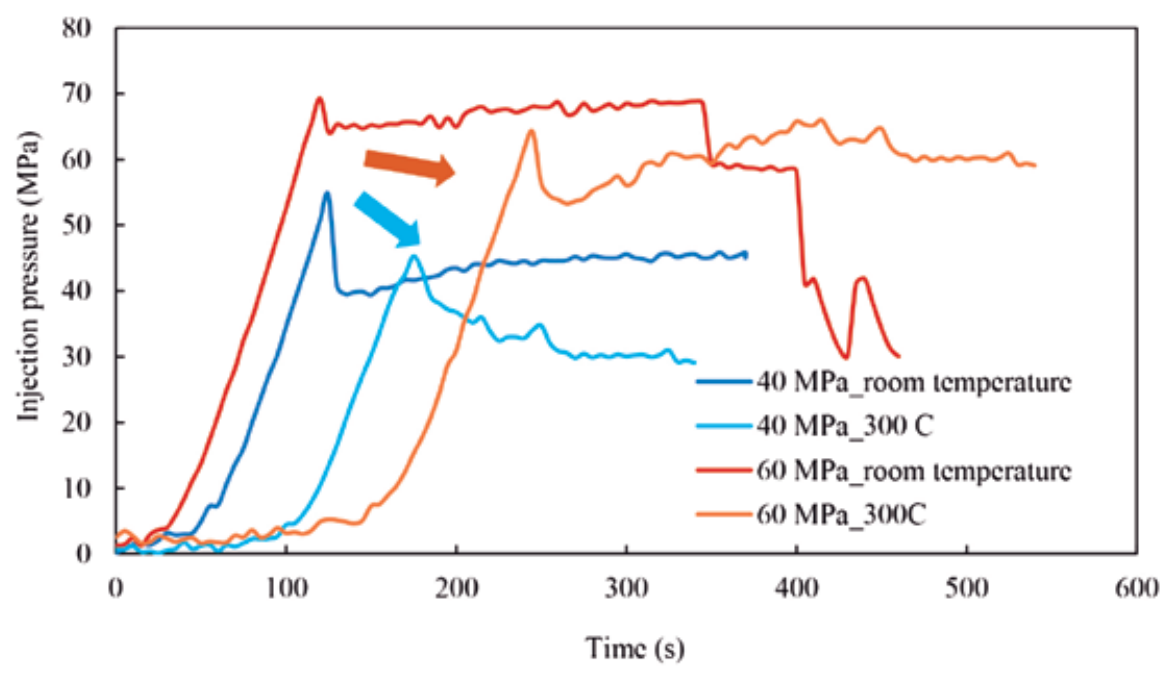

(b) Selected pressure time curves

Figure 4. Pressure time curves of hydraulic fracturing experiments. (a) Typical pressure time curve in hydraulic fracturing experiment (Sarmadivaleh, 2012). (b) Selected pressure time curves.

Figura 4. Curvas de tiempo-presión para los experimentos de fracturación hidráulica. (a) Típica curva tiempo-presión en el experimento de fracturación hidráulica (Sarmadivaleh, 2012). (b) Curvas tiempo-presión seleccionadas.

axial compressive loading. Fig. 8 represents the variation of normalized uniaxial compressive strength (UCS), elastic modulus and the Poisson's ratio of granite at different temperatures. Here the normalization was performed by dividing UCS, elastic modulus and the Poisson's ratio at the target temperature with the respective material property under room temperature conditions. It was identified that both the UCS and elastic modulus decrease non-linearly with increasing temperature. In general, the reductions were insignificant up $200^{\circ} \mathrm{C}$. However, substantial reductions were observed at higher temperatures. Due to the anisotropy of the rock matrix (presence of different minerals with different thermo-elastic coefficients), differential thermal expansion may result in initiation and propagation of both inter-and intra-granular fractures, depending on the induced thermal gradient (Homand-Etienne and Houpert, 1989). This can result in the reduction of the strength and elastic properties of granite, as observed in Fig.8. In addition, a substantial reduction of both UCS and elastic modulus was observed beyond $600{ }^{\circ} \mathrm{C}$, possibly as a result of the a 


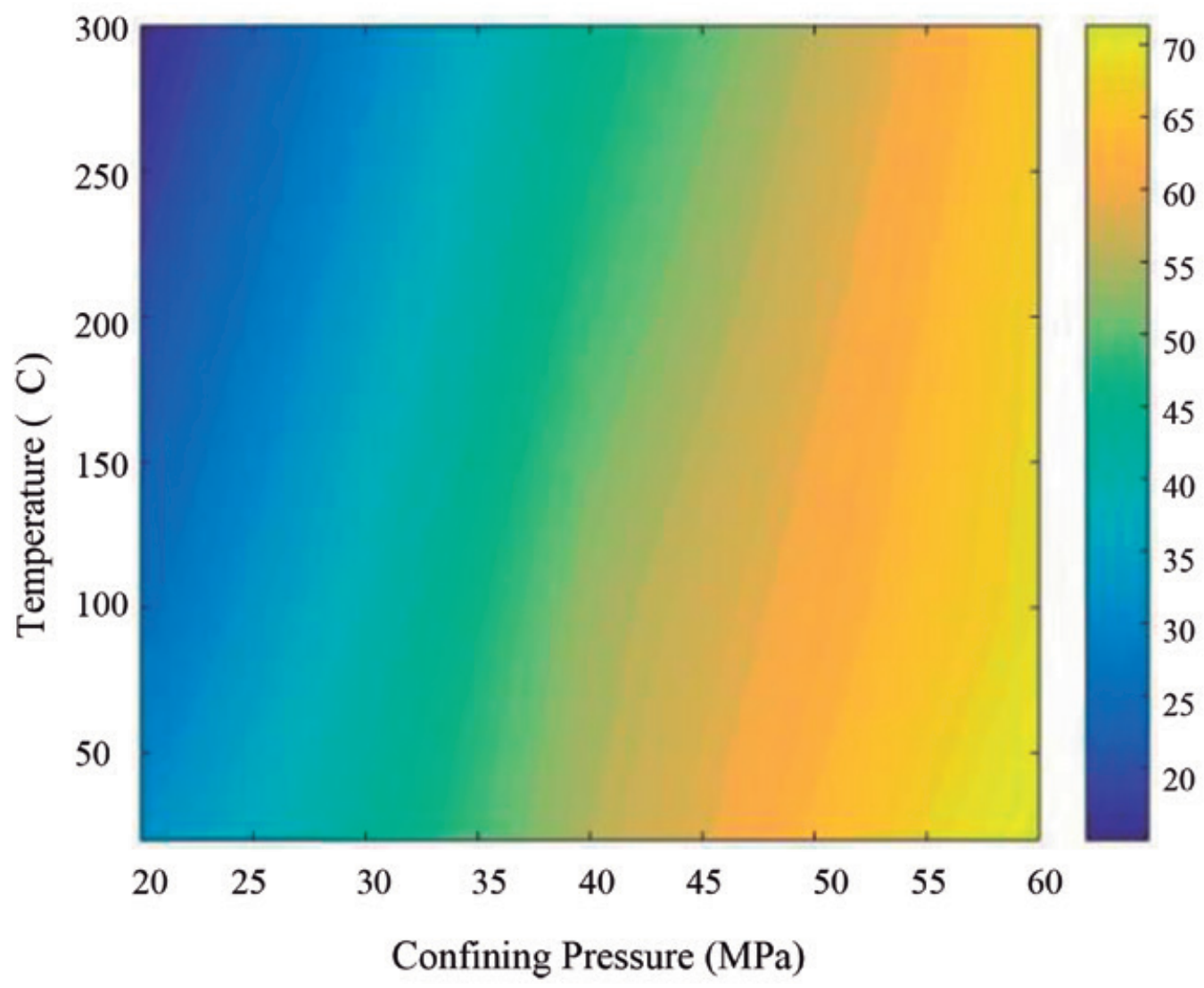

Figure 5. Variation of breakdown pressure for different temperatures and pressures.

Figura 5. Variación de la presión de ruptura para diferentes temperaturas y presiones.

to $\beta$ transition of quartz which occurs at $573^{\circ} \mathrm{C}$ (Ohno, 1995). In addition, the reduction of UCS and the elastic modulus were minimal beyond $700{ }^{\circ} \mathrm{C}$ due to the loss of material integrity beyond this temperature.

The Poisson's ratio of the granite was calculated using axial and transverse strain plots and it was found that an initial reduction of the Poisson's ratio occurred up to $300{ }^{\circ} \mathrm{C}$, followed by a substantial non-linear increment at higher temperatures. The initial reduction of the Poisson's ratio further confirmed the generation of micro-cracks due to the induced thermal gradient (Walsh, 1965). However, the transitional characteristics beyond $400{ }^{\circ} \mathrm{C}$ demonstrated increment of transverse strain compared to the axial strain, possibly due to the enhancement of the ductile characteristics of the material (Greaves et al., 2011). The brittle-ductile transition of granite has been identified by a number of authors (Xu et al., 2008; Shao et al., 2014) to be around $500-600{ }^{\circ} \mathrm{C}$. However, the present study suggests that due to the sudden thermal damage of the quenching treatment, early transitional characteristics can be expected at lower temperatures.

\section{Effect of rock micro-structure during thermal fracturing}

Next, in order to understand the structural alteration and corresponding flow enhancement of granite, micro-scale studies were conducted using SEM and micro-CT scanning technology. The following section summarises the results obtained for quenched samples treated at $600^{\circ} \mathrm{C}$.

Fig. 9 represents selected SEM images of the thin section treated at $600^{\circ} \mathrm{C}$. Images were taken at different magnifications to provide an understanding of the general and close-up views of the thermally induced fractures. A significant impact on the rock micro-structure was observed with both inter- and intra- crystalline cracks with fracture apertures ranging up to 30 $\mu \mathrm{m}$. Generally, the fracture aperture was smaller $1<$ $10 \mu \mathrm{m})$ for inter-crystalline fractures compared to the grain boundary cracks. Next, EDX technology was combined with SEM imaging and the corresponding minerals were qualitatively identified. For simplicity, the selected granite was represented by a three-mineral system of quartz, feldspar, and biotite. The XRD 


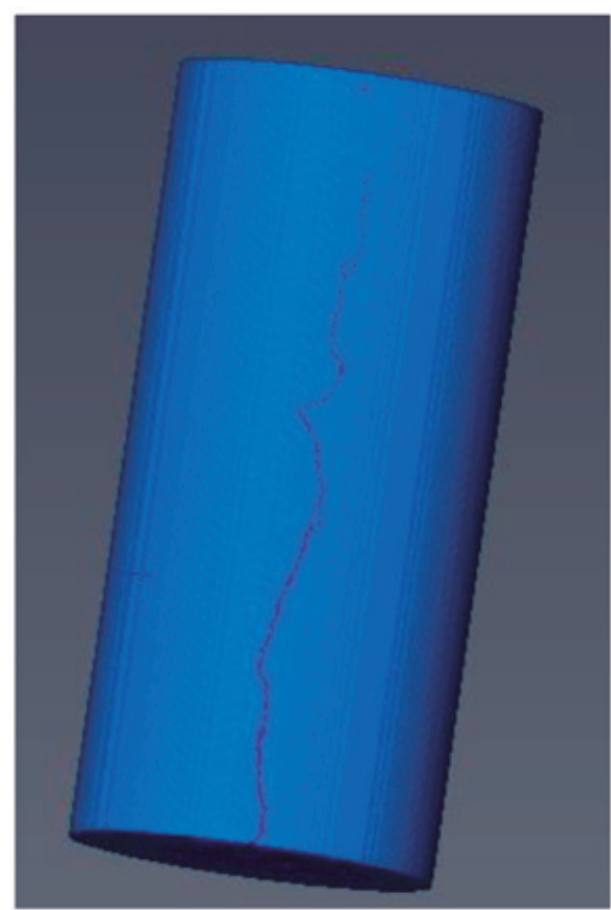

(a) Propagation of hydraulic fracture

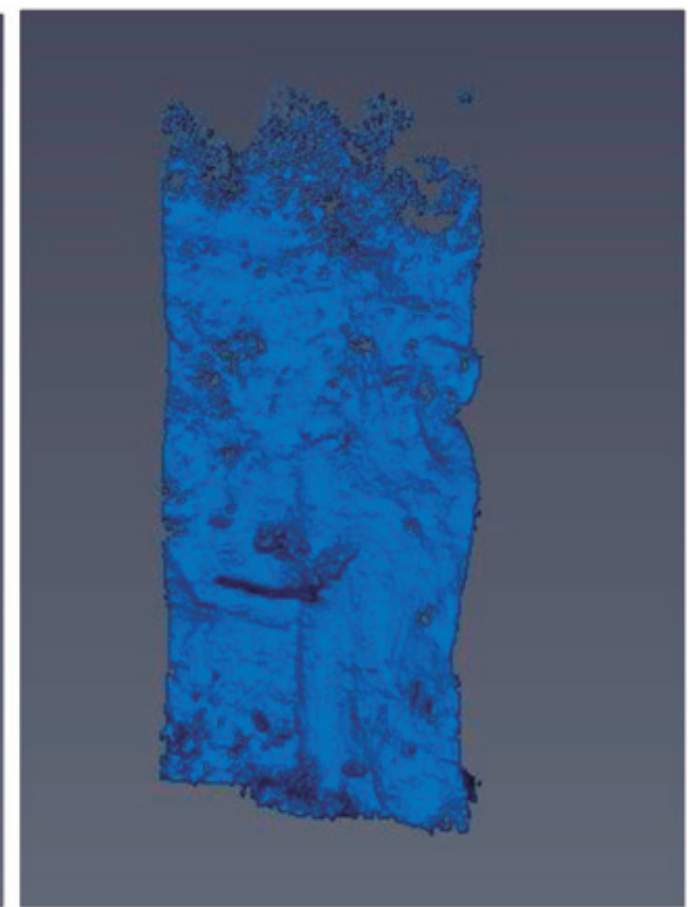

(b) Separated fracture profile

Figure 6. Re-constructed micro-CT images after hydraulic fracturing. (a) Propagation of hydraulic fracture. (b) Separated fracture profile. Figura 6. Imágenes CT reconstruidas después de la fracturación hidráulica. (a) Propagación de fractura hidráulica. (b) Perfil separado por fractura.

analysis (Table 3 ) was consistent with this simplification, since over $90 \%$ of the constituent minerals of the granite were in these categories (50\% quartz, $29 \%$ feldspar and $15 \%$ biotite). Next, the thermally induced fractures were quantified in terms of fracture types and Fig. 10 summarises the outcomes.

The figure indicates that quartz is the primary mineral prone to cracking due to thermal treatment compared with the other minerals. It should be noted that quartz is the most abundant mineral in this granite (over $50 \%$ by weight) which may be the primary reason for this observation. However, the normalized crack numbers with the mineral percentages also confirmed that quartz mineral has a higher susceptibility to cracking compared with biotite and feldspar. Studies have found a significant volumetric expansion of quartz compared with the other surrounding minerals (Fredrich and Wong, 1986). This may be the cause of having a larger number of cracks associated with quartz mineral. It was also identified that biotite mineral has considerable vulnerability to fracturing, par- ticularly as it has intra-crystalline fractures with small fracture apertures $(<2 \mu \mathrm{m})$ at high temperatures. This may be due to thermal damage to the layered mineral structure of biotite mineral (Fanning et al., 1989).

It was attempted to understand the nature of the induced fracture networks to identify whether they were connected or unconnected fractures and the flow performance of those induced fractures. CT images of the thermally treated granite were enhanced and reconstructed to understand the fracture profile using Avizo 9.2. Fig. 11 illustrates a 3-D profile of a selected 10 $\mathrm{mm}$ long section of the thermally treated sample and the corresponding separate induced fractures. The CT images confirmed that an unconnected large number of micro-fractures and an inter-connected micro- and macroscopic fracture network resulted due to the thermal treatment. Since the fluid transport characteristics are governed by well-interconnected fractures and large voids, a network of pores and throats was idealized using the pore network modelling (PNM) component of Avizo 9.2. Larger throat diameters and 


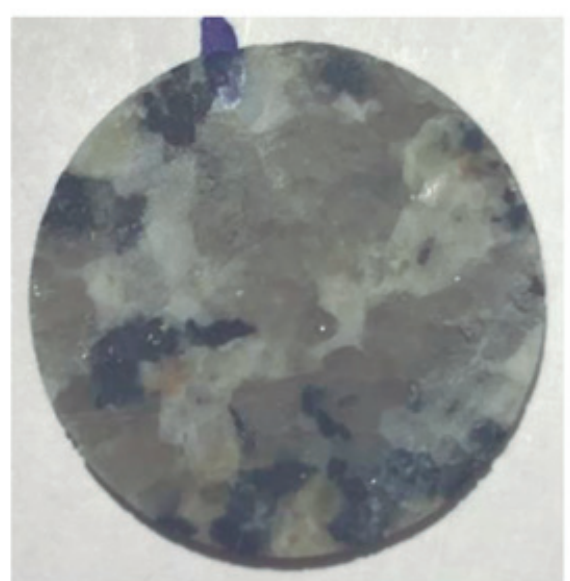

(a) Intact sample

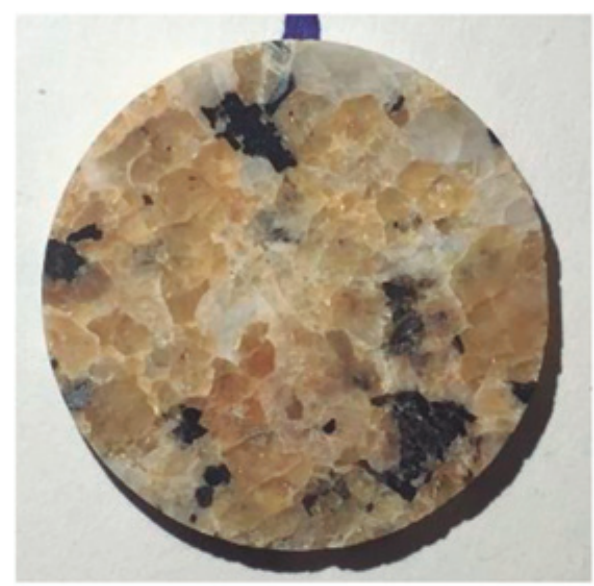

(c) $600{ }^{\circ} \mathrm{C}$

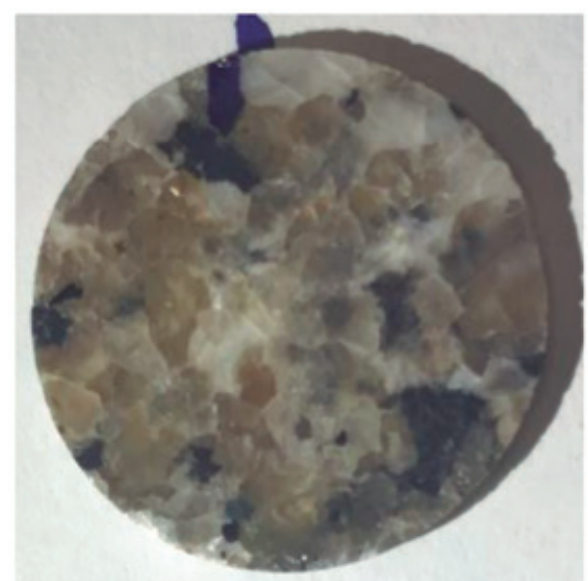

(b) $400^{\circ} \mathrm{C}$

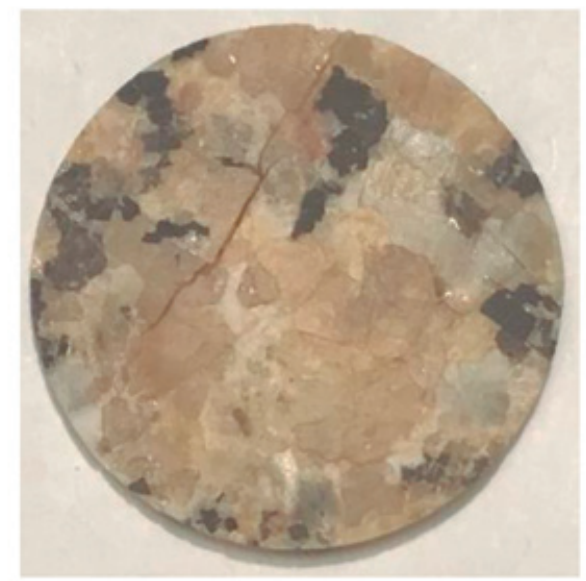

(c) $800^{\circ} \mathrm{C}$

Figure 7. Appearance of granite after different thermal treatments.

Figura 7. Apariencia del granito después de diferentes tratamientos térmicos.

well-developed flow channels were identified with inter-granular fractures of quartz-quartz minerals while other fractures contributed smaller throat diameters yet substantial enhancement of flow channels in the rock matrix. The volume fraction of the pores in the samples was $8.5 \%$, which was close to the fracture density calculated by surface fracture analysis using SEM imaging. It should be noted that the SEM images exhibit only 2-D microscopic structures of the surface and are incapable of providing the 3-D distribution and interconnectivity of fractures. Therefore, CT image analysis confirmed that the thermally induced interconnected fractures would provide major pathways to fluid transport. This was examined in the next experimental series.

\section{Permeability enhancement due to stimulation}

The fluid flow characteristics of intact and fractured granite were investigated by conducting drain permeability tests at room temperature. The tests were conducted at $10 \mathrm{MPa}$ confining pressure and the effective stress on the sample was gradually decreased by increasing the injection pressure. It was confirmed that the steady-state flow rate linearly increased with the pressure gradient across the sample, and the permeability was calculated by incorporating Darcy's equation.

Fig. 12 shows the permeability values of different samples calculated under different in-situ stress conditions. It was found that the permeability is approxi- 


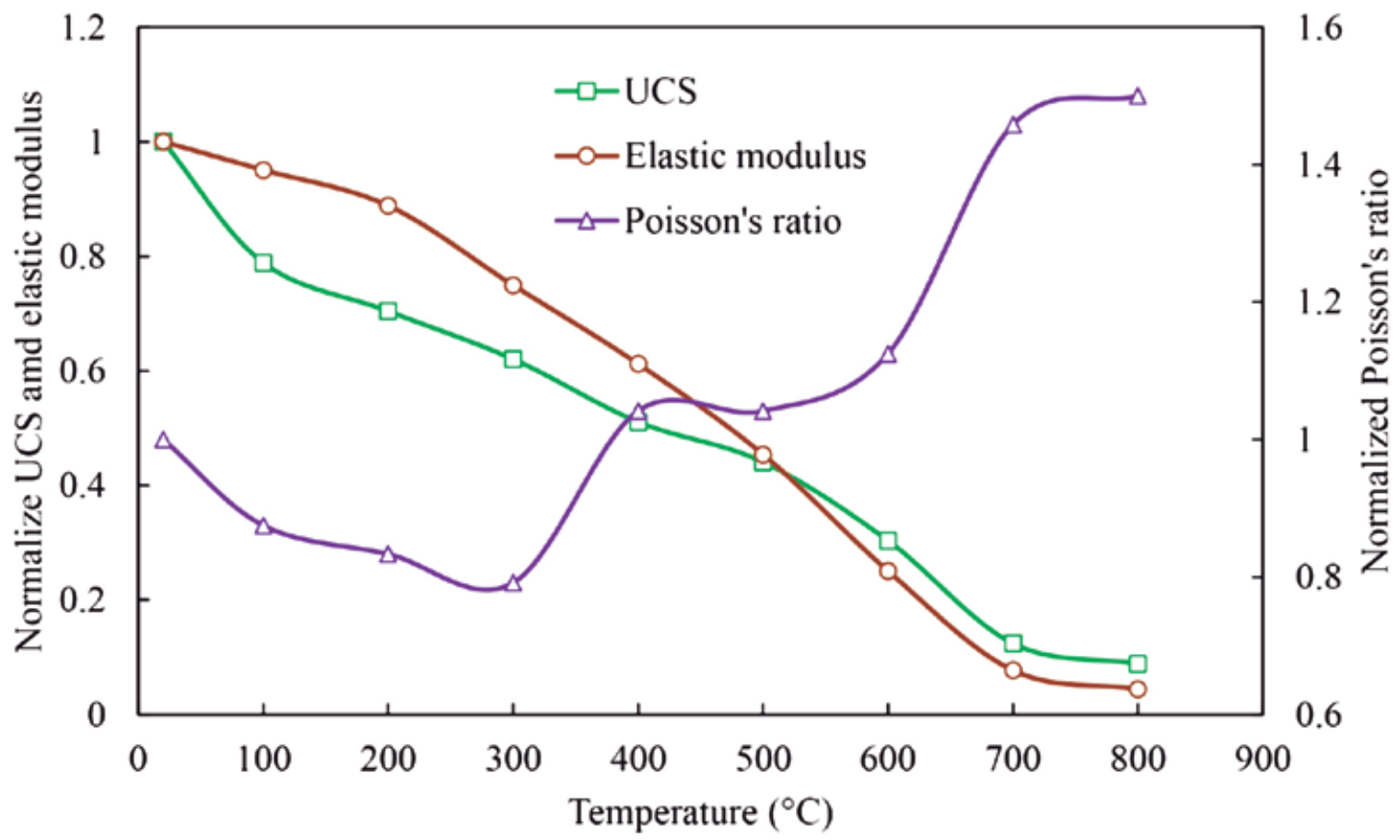

Figure 8. Variation of mechanical properties of granite with different thermal treatments.

Figura 8. Variación de las propiedades mecánicas del granito con diferentes tratamientos térmicos.
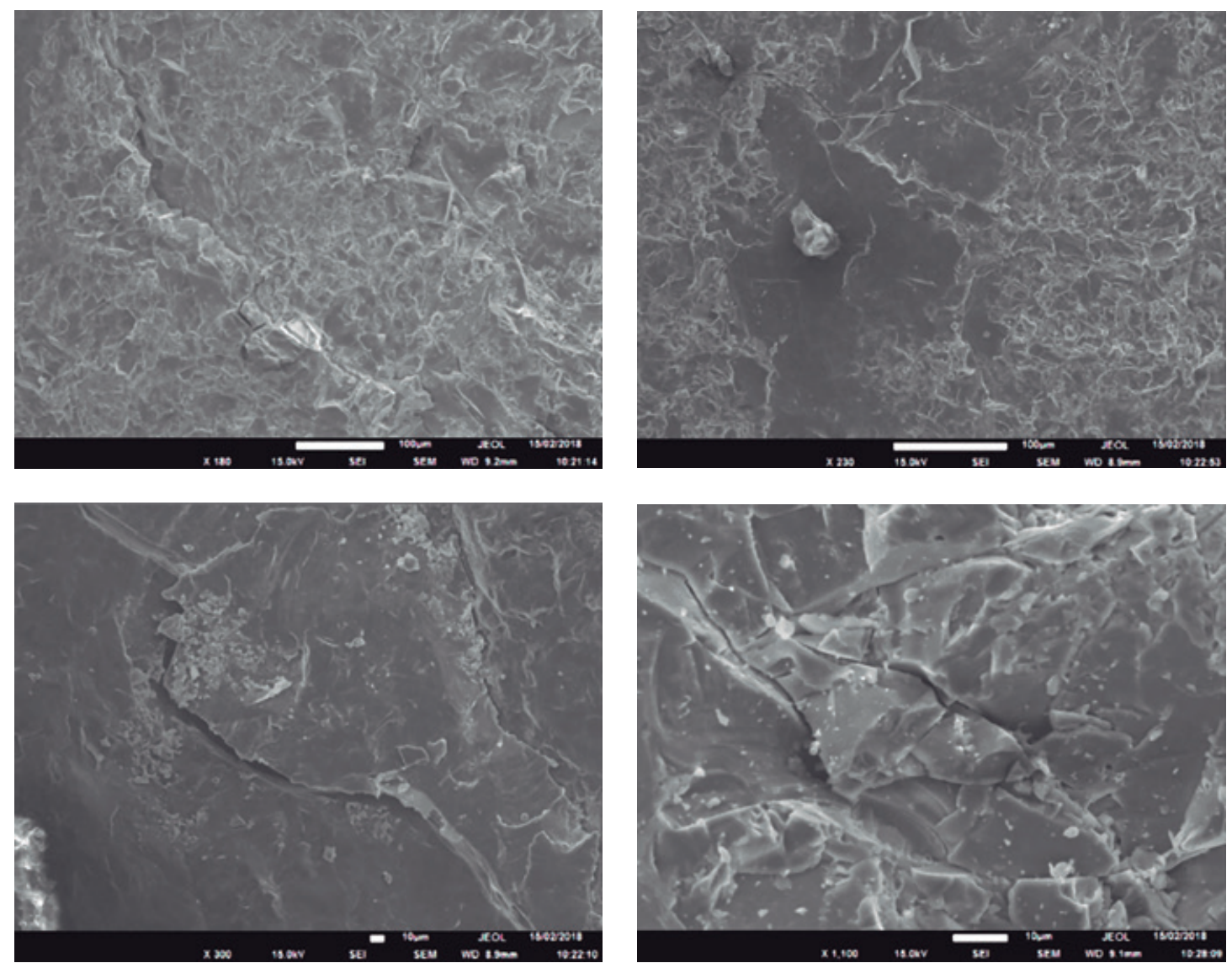

Figure 9. Identification of thermally induced cracks using SEM.

Figura 9. Identificación de grietas inducidas térmicamente utilizando SEM. 


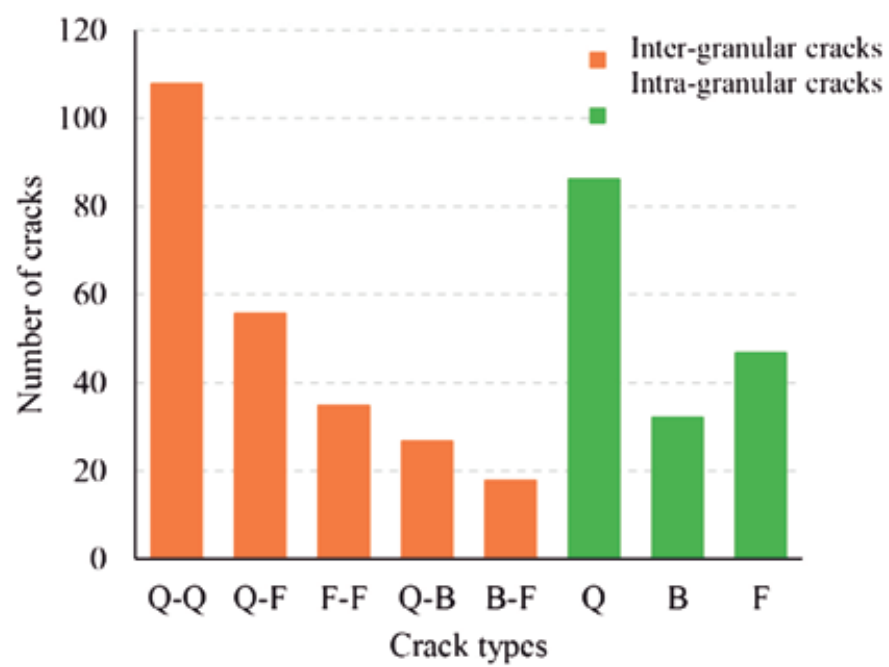

Q-Q: Quartz-quartz inter-granular cracks

Q-F: Quartz-feldspar inter-granular cracks

Q-Q: Feldspar - feldspar inter-granular cracks

Q-Q: Quartz-biotite inter-granular cracks

Q-Q: Biotite-feldspar inter-granular cracks

Q: Quartz intra-granular cracks

B: Biotite intra-granular cracks

F: Feldspar intra-granular cracks

Figure 10. Quantified thermally induced crack types.

Figura 10. Cuantificación de los tipos de fracturas inducidas térmicamente.

mately uniform across the considered effective stress ranges according to Darcy's equation. The permeability of the intact specimen under $10 \mathrm{MPa}$ confining pressure was negligible, at only about $0.1 \mu \mathrm{D}$. Substantial permeability increment was observed with the fractured specimens, such that 20 times permeably increment was found for the samples hydraulically fractured under room temperature conditions compared to the intact rock. The increment was 1 order higher for the sample hydraulically fractured at $300^{\circ} \mathrm{C}$ under the same stress conditions. Interestingly, the permeability of the thermally quenched sample at $600{ }^{\circ} \mathrm{C}$ was 4 orders higher than that of the intact specimen.

The experimental results clearly demonstrated that induced fractures play a crucial role in the flow characteristics of granite, which has very low intact permeability. As explained in the previous sections, in room-temperature hydraulic fracturing experiments, one single fracture is generally induced. However, in the absence of proppants the induced fracture can be closed under large normal stress. This can result in relatively low permeability enhancement although, with the induced fracture, the permeability is considerably higher under this condition. However, the injection of cold water into hot rock can create thermally induced micro-fractures, particularly in the wellbore zone, thereby enhancing the porosity of the material. The present experiments provide evidence that this may result in substantial enhancement of permeability compared to the previous condition. The flow performance of the material can be significantly enhanced by the enhanced thermal gradients. As identified by the $\mathrm{CT}$ images, following quenching treatment at 600 ${ }^{\circ} \mathrm{C}$, the crack density of rock is significantly enhanced, creating a network of interconnected macro- and micro-fractures. This results in significant enhancement of the transport characteristics of granite, which suggests that thermal stimulation combined with hydraulic fracturing may be an important reservoir stimulation technique in the geothermal environment (Kitao et al., 1990; Flores et al., 2005).

\section{Recommendations for future technology improvement}

Geothermal environments are associated with large confining stresses (usually from 20-60 MPa) and different temperature conditions $\left(100-300{ }^{\circ} \mathrm{C}\right.$ ) (Breede et al., 2013). Therefore, the induced hydraulic and thermal fractures are sensitive to stress and temperature changes and increasing confining pressures can cause non-linear reduction of permeability due to the closure of the fractures under greater effective stresses. In addition, increasing temperature results in permeability alteration due to thermally induced volumetric expansion, which leads to enhancement of the interlock effect and thermally induced damage. To overcome the re-closure problem, proppants, which are solid materials in fine particulate form (sand, sand, ceramic, chemicals, and gel), are generally used. However, these are not usually small enough to penetrate existing or generated micro-fractures (particularly thermal fractures with small fracture apertures) since these particles usually range from $500 \mu \mathrm{m}$ to $800 \mu \mathrm{m}$ (Liang et al., 2016). The injection of nano-sized parti- 


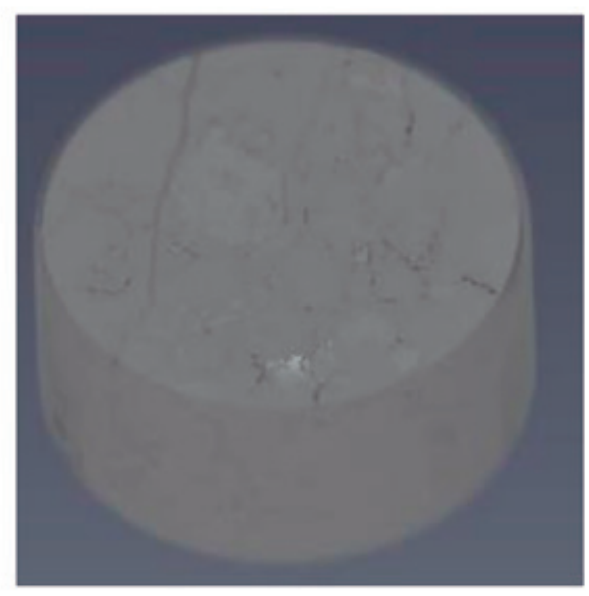

(a) Separated 3-D profile of thermally fractured granite

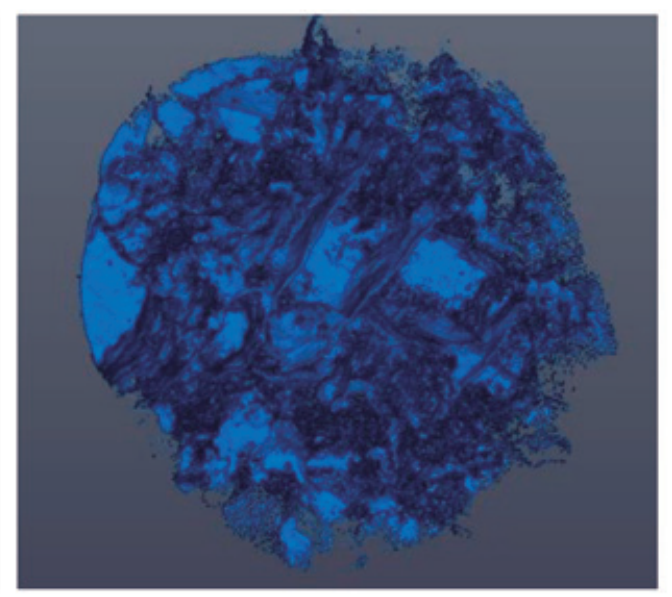

(b) Separated fracture profile

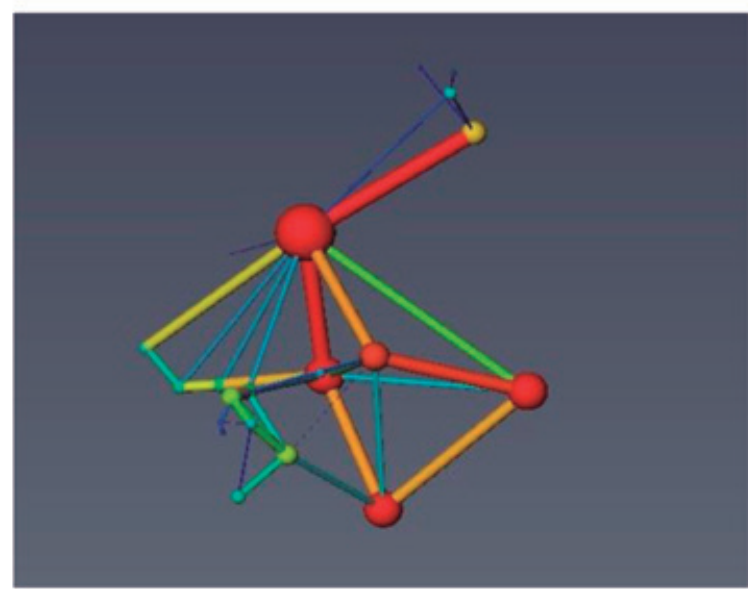

(c) Pore-network model for the selected granite section

Figure 11. Re-constructed micro-CT images after thermal fracturing. (a) Separated 3-D profile of thermally fractured granite. (b) Separated fracture profile. (c) Pore-network model for the selected granite section.

Figura 11. Imágenes CT reconstruidas después de la fracturación térmica. (a) Perfil tridimensional separado del granito fracturado térmicamente. (b) Perfil desagregrado de fractura. (c) Modelo de red de poros para la sección del granito seleccionado.

cles followed by conventional large proppants has been hypothesized to widen the induced fractures and allow them to open (Bose et al., 2015). However, the applicability of nano-proppants for fracture conductivity improvement under geothermal conditions is poorly understood to date, and it is essential to assess their long-term chemical and thermal stability under geothermal reservoir conditions.

It is critical to enhance and extend hydraulically- and thermally induced fractures, which may be achieved by the use of improved fracturing fluids, intermittent fluid injection at higher pumping rates, increasing the thermal gradient and cyclic thermal loading. However, the corresponding permeability enhancement of these treatments needs to be confirmed based on comprehensive research. It is strongly recommended to combine micro- and meso-scale experiments to understand the fundamentals of the coupled process and quantify the process parameters. Combined experimental studies can provide knowledge of the underlying mechanisms 


\section{Injection Pressure (MPa)}

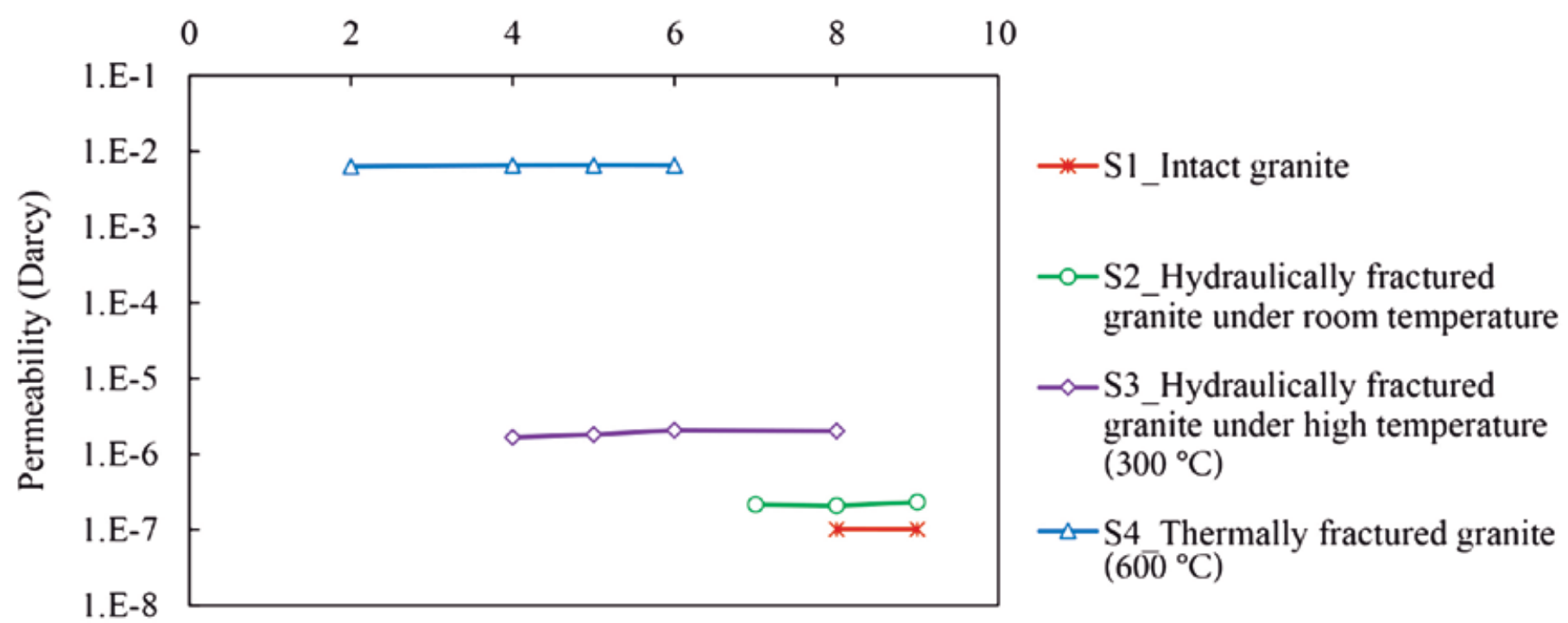

Figure 12. Permeability enhancement upon hydraulic and thermal fracturing.

Figura 12. Aumento de la permeabilidad como consecuencia de la fracturación hidráulica y térmica.

and physics of geothermal reservoir rocks in terms of their fracture and pore geometry, the fluid flow along these complex geometries, thermally induced damage and chemical interactions with different fluids. For example, micro-scale and meso-scale experiments can be combined, as discussed in this paper. It is strongly suggested to conduct macro-scale experiments on large rock samples and then combine the results with fieldscale tests and in-situ reservoir modelling. This would avoid costly errors in the creation and maintenance of EGS reservoirs in the industrial context.

\section{Conclusions}

This paper discusses hydraulic and thermal stimulation techniques employed in unconventional geothermal systems based on combined meso- and micro- scale laboratory experiments. Recent literature on the topic has been comprehensively reviewed, and future research directions to enhance current technology have been proposed. The major findings from the study can be summarised as follows:

- Laboratory hydraulic fracturing experiments confirm that the breakdown pressure of reservoir rock increases linearly with reservoir depth (confining pressure). With regard to high-temperature experiments, breakdown pressure decreases linearly with increasing temperature.
The fracture propagation path and the aperture are mainly controlled by the stress state and the heterogeneity of the rock matrix. CT images confirm that one single fracture is induced in room temperature hydraulic fracturing. However, a perforated zone with multiple inter-crystalline cracks is induced in the wellbore zone apart from the main fracture in high-temperature hydraulic fracturing.

- Increasing the thermal gradient results in the non-linear reduction of uniaxial compressive strength and Young's modulus due to thermal weakening which is confirmed by microstructural analysis. The initial reduction of the Poisson's ratio up to $300{ }^{\circ} \mathrm{C}$ is followed by a substantial non-linear increment at higher temperatures.

- Quartz is the primary mineral prone to cracking due to thermal treatment compared with biotite and feldspar. This is due to the abundance of quartz mineral and its significant volumetric expansion compared with the surrounding minerals. Further, CT images confirm that an unconnected large number of micro-fractures and an inter-connected micro- and macroscopic fracture network result due to thermal treatment.

- A substantial permeability increment is observed with fractured specimens, such that 20 times permeability increment was found for samples hydraulically fractured under room temperature 
conditions compared with intact rock. The increment was 1 order higher for a sample hydraulically fractured at $300{ }^{\circ} \mathrm{C}$ under the same stress conditions. Interestingly, the permeability of a sample thermally quenched at $600^{\circ} \mathrm{C}$ was 4 orders higher than that of an intact specimen.

\section{References}

Blanton, T. L. An experimental study of interaction between hydraulically induced and pre-existing fractures. SPE Unconventional Gas Recovery Symposium, 1982. Society of Petroleum Engineers.

Bose, C. C., Gul, A., Fairchild, B., Jones, T. \& Barati, R. Nano-proppants for fracture conductivity improvement and fluid loss reduction. SPE Western Regional Meeting, 2015. Society of Petroleum Engineers.

Breede, K., Dzebisashvili, K., Liu, X. \& Falcone, G. 2013. A systematic review of enhanced (or engineered) geothermal systems: past, present and future. Geothermal Energy, 1, 4.

Bunger, A., Jeffrey, R., Kear, J., Zhang, X. \& Morgan, M. Experimental investigation of the interaction among closely spaced hydraulic fractures. 45th US Rock Mechanics/ Geomechanics Symposium, 2011. American Rock Mechanics Association.

Bunger, A. P., Jeffrey, R. G. \& Detournay, E. Application of scaling laws to laboratory-scale hydraulic fractures. Alaska Rocks 2005, The 40th US Symposium on Rock Mechanics (USRMS), 2005. American Rock Mechanics Association.

Chitrala, Y., Moreno, C., Sondergeld, C. \& Rai, C. 2013. An experimental investigation into hydraulic fracture propagation under different applied stresses in tight sands using acoustic emissions. Journal of Petroleum Science and Engineering, 108, 151-161.

Deng, J., Lin, C., Yang, Q., Liu, Y., Tao, Z. \& Duan, H. 2016. Investigation of directional hydraulic fracturing based on true tri-axial experiment and finite element modeling. Computers and Geotechnics, 75, 28-47.

Dmitriev, A. P. 1972. Physical properties of rocks at high temperatures, National Aeronautics and Space Administration; National Technical Information Service, Springfield, Va.

Dwivedi, R. D., Goel, R. K., Prasad, V. V. R. \& Sinha, A. 2008. Thermo-mechanical properties of Indian and other granites. International Journal of Rock Mechanics and Mining Sciences, 45, 303-315.

El Rabaa, W. Experimental study of hydraulic fracture geometry initiated from horizontal wells. SPE Annual Technical Conference and Exhibition, 1989. Society of Petroleum Engineers.>PAGES?<

Fallahzadeh, S., Rasouli, V. \& Sarmadivaleh, M. 2015. An investigation of hydraulic fracturing initiation and near-wellbore propagation from perforated boreholes in tight formations. Rock Mechanics and Rock Engineering, 48, 573-584.

Fan, T.-G. \& Zhang, G.-Q. 2014. Laboratory investigation of hydraulic fracture networks in formations with continuous orthogonal fractures. Energy, 74, 164-173.

Fanning, D. S., Keramidas, V. Z. \& El-Desoky, M. A. 1989. Micas. Minerals in soil environments, 551-634.

Flores, M., Davies, D., Couples, G. \& Palsson, B. Stimulation of geothermal wells: can we afford it? Proceedings World Geothermal Congress, 2005. 1.

Fredrich, J. T. \& Wong, T. F. 1986. Micromechanics of thermally induced cracking in three crustal rocks. Journal of Geophysical Research: Solid Earth, 91, 12743-12764.

Geraud, Y. 1994. Variations of connected porosity and inferred permeability in a thermally cracked granite. Geophysical Research Letters, 21, 979-982.

Gischig, V. S. \& Preisig, G. Hydro-fracturing versus hydro-shearing: a critical assessment of two distinct reservoir stimulation mechanisms. 13th ISRM International Congress of Rock Mechanics, 2015. International Society for Rock Mechanics.

Greaves, G. N., Greer, A., Lakes, R. \& Rouxel, T. 2011. Poisson's ratio and modern materials. Nature Materials, 10, 823-837.

Guo, T., Zhang, S., Qu, Z., Zhou, T., Xiao, Y. \& Gao, J. 2014. Experimental study of hydraulic fracturing for shale by stimulated reservoir volume. Fuel, 128, 373-380.

Haimson, B. \& Fairhurst, C. 1967. Initiation and extension of hydraulic fractures in rocks. Society of Petroleum Engineers Journal, 7, 310-318.

Heard, H. 1989. Thermal stress cracking in granite. Journal of Geophysical Research, 94, 1745-1758.

Heuze, F. High-temperature mechanical, physical and thermal properties of granitic rocks - a review. International Journal of Rock Mechanics and Mining Sciences \& Geomechanics Abstracts, 1983. Elsevier, 3-10.

Hogarth, R., Holl, H. \& McMahon, A. Flow testing results from Habanero EGS Project. Proceedings Australian Geothermal Energy Conferences, 2013.

Huenges, E. “Enhanced geothermal systems: Review and status of research and development." Geothermal Power Generation. 2016. 743-761.Hussain, A., Arif, S. M. \& Aslam, M. 2017. Emerging renewable and sustainable energy technologies: State of the art. Renewable and Sustainable Energy Reviews, 71, 12-28.

Jung, R., 2013, May. EGS-goodbye or back to the future. In ISRM International Conference for Effective and Sustainable Hydraulic Fracturing. International Society for Rock Mechanics and Rock Engineering.

Kitao, K., Ariki, K., Hatakeyama, K. \& Wakita, K. 1990. Well stimulation using cold-water injection experiments in the Sumikawa geothermal field, Akita prefecture, Japan. Geothermal Resource Council Transactions, 14, 1219-1224. 
Kumari, W., Ranjith, P., Perera, M., Shao, S., Chen, B., Lashin, A., Al Arifi, N. \& Rathnaweera, T. 2017. Mechanical behaviour of Australian Strathbogie granite under in-situ stress and temperature conditions: An application to geothermal energy extraction. Geothermics, 65, 44-59.

Kumari, W. G. P., Ranjith, P. G., Perera, M. S. A., Li, X., Li, L. H., Chen, B. K., Isaka, B. L. A. \& Silva, V. R. S. D. 2018. Hydraulic fracturing under high temperature and pressure conditions with micro CT applications: Geothermal energy from hot dry rocks. Fuel, 230, 138-154.

Lemmon, E. W., Huber, M. L. \& Mclinden, M. O. 2002. NIST reference fluid thermodynamic and transport propertiesREFPROP. NIST standard reference database, 23, v7.

Liang, F., Sayed, M., Al-Muntasheri, G. A., Chang, F. F. \& Li, L. 2016. A comprehensive review on proppant technologies. Petroleum, 2, 26-39.

Mao, R., Feng, Z., Liu, Z. \& Zhao,Y. 2017. Laboratory hydraulic fracturing test on large-scale pre-cracked granite specimens. Journal of Natural Gas Science and Engineering, 44, 278-286.

Ohno, I. 1995. Temperature variation of elastic properties of alpha quartz up to the alpha beta transition. Journal of Physics of the Earth, 43, 157-169.

Sarmadivaleh, M. 2012. Experimental and numerical study of interaction of a pre-existing natural interface and an induced hydraulic fracture. PhD, Curtin University.

Sarmadivaleh, M., Joodi, B., Nabipour, A. \& Rasouli, V. 2013. Steps to conducting a valid hydraulic-fracturing laboratory test. The APPEA Journal, 53, 347-354.

Schill, E., Cuenot, N., Genter, A. \& Kohl, T. Review of the hydraulic development in the multi-reservoir/multi-well EGS project of Soultz-sous-Forets. Proceedings World Geothermal Congress 2015, 2015. 19-25.

Shao, S. 2015. Coupled Thermo-Hydro-Mechanical (THM) Behaviour of Rock Relevant to the Geothermal Industry (Doctoral dissertation). PhD, Monash University.

Shao, S., Wasantha, P. L. P., Ranjith, P. G. \& Chen, B. K. 2014. Effect of cooling rate on the mechanical behavior of heated Strathbogie granite with different grain sizes. International Journal of Rock Mechanics and Mining Sciences, 70, 381-387.

Siratovich, P. A., Villeneuve, M. C., Cole, J. W., Kennedy, B. M. \& Bégué, F. 2015. Saturated heating and quenching of three crustal rocks and implications for thermal stimulation of permeability in geothermal reservoirs. International Journal of Rock Mechanics and Mining Sciences, 80, 265-280.

Stephens, G. \& Voight, B. 1982. Hydraulic fracturing theory for conditions of thermal stress. International Journal of
Rock Mechanics and Mining Sciences \& Geomechanics Abstracts, 19, 279-284.

Tarasovs, S. and Ghassemi, A., 2011, January. Propagation of a system of cracks under thermal stress. In 45th US Rock Mechanics/Geomechanics Symposium. American Rock Mechanics Association.

Walsh, J. 1965. The effect of cracks in rocks on Poisson's ratio. Journal of Geophysical Research, 70, 5249-5257.

Wanniarachchi, W.A.M., Gamage, R.P., Perera, M.S.A., Rathnaweera, T.D., Gao, M. and Padmanabhan, E., 2017. Investigation of depth and injection pressure effects on breakdown pressure and fracture permeability of shale reservoirs: an experimental study. Applied Sciences, 7(7), p.664. Watanabe, K. \& Takahashi, H. 1995. Fractal geometry characterization of geothermal reservoir fracture networks. Journal of Geophysical Research: Solid Earth (1978-2012), 100, 521-528.

Wong, T.-F. 1982. Effects of temperature and pressure on failure and post-failure behavior ofWesterly granite. Mechanics of Materials, 1, 3-17.

Wong, T.-F. \& Brace, W. 1979. Thermal expansion of rocks: some measurements at high pressure. Tectonophysics, 57, 95-117.

Xu, X.-L., Gao, F., Shen, X.-M. \& Xie, H.-P. 2008. Mechanical characteristics and microcosmic mechanisms of granite under temperature loads. Journal of China University of Mining and Technology, 18, 413-417.

Yasuhara, H. \& Elsworth, D. 2008. Compaction of a rock fracture moderated by competing roles of stress corrosion and pressure solution. Pure and Applied Geophysics, 165, 1289-1306.

Zhou, C., Wan, Z., Zhang, Y. \& Gu, B. 2018. Experimental study on hydraulic fracturing of granite under thermal shock. Geothermics, 71, 146-155.

Zhou, J., Chen, M., Jin, Y. \& Zhang, G.-Q. 2008. Analysis of fracture propagation behavior and fracture geometry using a tri-axial fracturing system in naturally fractured reservoirs. International Journal of Rock Mechanics and Mining Sciences, 45, 1143-1152.

Zimmermann, G. \& Reinicke, A. 2010. Hydraulic stimulation of a deep sandstone reservoir to develop an Enhanced Geothermal System: Laboratory and field experiments. Geothermics, 39, 70-77.

Zoback, M., Rummel, F., Jung, R. \& Raleigh, C. 1977. Laboratory hydraulic fracturing experiments in intact and pre-fractured rock. International Journal of Rock Mechanics and Mining Sciences \& Geomechanics Abstracts, 14, 49-58.

Recibido: julio 2019

Revisado: noviembre 2019

Aceptado: enero 2020

Publicado: marzo 